\title{
The Arctic Research of the Composition of the Troposphere from Aircraft and Satellites (ARCTAS) mission: design, execution, and first results
}

\author{
D. J. Jacob ${ }^{1}$, J. H. Crawford ${ }^{2}$, H. Maring ${ }^{3}$, A. D. Clarke ${ }^{4}$, J. E. Dibb ${ }^{5}$, L. K. Emmons ${ }^{6}$, R. A. Ferrare ${ }^{2}$, C. A. Hostetler ${ }^{2}$, \\ P. B. Russell ${ }^{7}$, H. B. Singh ${ }^{7}$, A. M. Thompson ${ }^{8}$, G. E. Shaw ${ }^{9}$, E. McCauley ${ }^{10}$, J. R. Pederson ${ }^{10}$, and J. A. Fisher ${ }^{1}$ \\ ${ }^{1}$ Harvard University, Cambridge, Massachusetts, USA \\ ${ }^{2}$ NASA Langley Research Center, Hampton, Virginia, USA \\ ${ }^{3}$ NASA Headquarters, Washington DC, USA \\ ${ }^{4}$ University of Hawaii, Honolulu, Hawaii, USA \\ ${ }^{5}$ University of New Hampshire, Durham, New Hampshire, USA \\ ${ }^{6}$ National Center for Atmospheric Research, Boulder, Colorado, USA \\ ${ }^{7}$ NASA Ames Research Center, Moffett Field, California, USA \\ ${ }^{8}$ Pennsylvania State University, State College, Pennsylvania, USA \\ ${ }^{9}$ University of Alaska, Fairbanks, Alaska, USA \\ ${ }^{10}$ California Air Resources Board, Sacramento, California, USA
}

Received: 23 July 2009 - Published in Atmos. Chem. Phys. Discuss.: 12 August 2009

Revised: 3 June 2010 - Accepted: 4 June 2010 - Published: 14 June 2010

\begin{abstract}
The NASA Arctic Research of the Composition of the Troposphere from Aircraft and Satellites (ARCTAS) mission was conducted in two 3-week deployments based in Alaska (April 2008) and western Canada (June-July 2008). Its goal was to better understand the factors driving current changes in Arctic atmospheric composition and climate, including (1) influx of mid-latitude pollution, (2) boreal forest fires, (3) aerosol radiative forcing, and (4) chemical processes. The June-July deployment was preceded by one week of flights over California (ARCTAS-CARB) focused on (1) improving state emission inventories for greenhouse gases and aerosols, (2) providing observations to test and improve models of ozone and aerosol pollution. ARCTAS involved three aircraft: a DC-8 with a detailed chemical payload, a P-3 with an extensive aerosol and radiometric payload, and a B-200 with aerosol remote sensing instrumentation. The aircraft data augmented satellite observations of Arctic atmospheric composition, in particular from the NASA A-Train. The spring phase (ARCTAS-A) revealed pervasive Asian pollution throughout the Arctic as well as significant European pollution below $2 \mathrm{~km}$. Unusu-
\end{abstract}

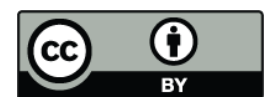

Correspondence to: D. J. Jacob (djacob@fas.harvard.edu) ally large Siberian fires in April 2008 caused high concentrations of carbonaceous aerosols and also affected ozone. Satellite observations of $\mathrm{BrO}$ column hotspots were found not to be related to Arctic boundary layer events but instead to tropopause depressions, suggesting the presence of elevated inorganic bromine (5-10 pptv) in the lower stratosphere. Fresh fire plumes from Canada and California sampled during the summer phase (ARCTAS-B) indicated low $\mathrm{NO}_{\mathrm{x}}$ emission factors from the fires, rapid conversion of $\mathrm{NO}_{\mathrm{x}}$ to PAN, no significant secondary aerosol production, and no significant ozone enhancements except when mixed with urban pollution.

\section{Introduction}

The Arctic Research of the Composition of the Troposphere from Aircraft and Satellites (ARCTAS) mission was conducted in April and June-July 2008 by the Global Tropospheric Chemistry Program and the Radiation Sciences Program of the US National Aeronautics and Space Administration (NASA). Its objective was to better understand the factors driving current changes in Arctic atmospheric composition and climate. It used chemical and radiative measurements from three research aircraft (DC-8, P-3, B-200) to

Published by Copernicus Publications on behalf of the European Geosciences Union. 
interpret and augment the continuous observations of Arctic atmospheric composition from satellites. The aircraft were based in Alaska in April (ARCTAS-A) and in western Canada in June-July (ARCTAS-B). ARCTAS was part of the international POLARCAT program of field observations of Arctic atmospheric composition during the 2007-2008 International Polar Year (http://www.polarcat.no/) and was coordinated with several concurrent field programs. This paper provides an overview of the ARCTAS mission and a synthesis of first results.

The Arctic has been warming rapidly over the past century, and the pace has accelerated in the past decades (Trenberth et al., 2007). Sea ice cover and permafrost show rapid declines (Lemke et al., 2007). General circulation models (GCMs) project strong 21 st-century warming in the Arctic, reflecting in part the sea ice feedback (Christensen et al., 2007). Even so, these models underestimate the observed warming over the past decades (Shindell and Faluvegi, 2009), suggesting that they might underestimate future warming. One possible factor missing from current climate models is proper representation of the regional radiative forcing from aerosols and tropospheric ozone, which may be particularly important in the Arctic (Law and Stohl, 2007; Shindell et al., 2007; Quinn et al., 2008). Decreasing the forcing from these short-lived agents could provide an opportunity to curb Arctic warming. The primary goal of ARCTAS was to better understand the sources of aerosols and tropospheric ozone in the Arctic, as well as the radiative properties of Arctic aerosols and of the underlying surface, in order to improve estimates of the associated radiative forcings.

Inflow of pollution from northern mid-latitudes is a wellknown source of aerosols and ozone to the Arctic. It prompts not only climatic but air quality and ecological concerns. It has been known for decades that the Arctic is heavily affected by mid-latitude pollution in winter-spring, manifested by visible "Arctic haze" aerosol layers (Radke et al., 1984; Barrie and Hoff, 1985; Brock et al., 1989; Shaw, 1995). Arctic observations have been mostly at the surface, leading to the conventional view of a strong seasonal variation in midlatitude pollution inflow with northern Eurasia as the dominant contributor (Rahn, 1981; Barrie, 1986). However, recent models and limited observations show transport from mid-latitudes taking place year-round through different processes at different altitudes and involving all three source continents (Klonecki et al., 2003; Koch and Hansen, 2005; Stohl, 2006; Shindell et al., 2008). Sources at mid-latitudes are rapidly changing, with increases in Asia driven by industrialization and decreases in North America and Europe driven by air quality regulations. Better understanding of pollution transport to the Arctic and of the associated sourcereceptor relationships was a priority for ARCTAS.

Chemical processing plays a major role in the evolution of aerosols, ozone, and other pollutants in the Arctic. The chemical environment in the Arctic is characterized by remoteness, intense cold, and long periods of light and dark- ness. Photochemical reactions on snow and sea ice surfaces following the winter darkness provide a springtime source of halogen radicals that drive rapid ozone destruction and mercury oxidation (Simpson et al., 2007a). Halogen radical generation may be highly sensitive to climate change through sea ice cover (Simpson et al., 2007b). A goal of ARCTAS was to better understand the radical photochemistry of the Arctic atmosphere and its implications for the regional budgets of aerosols, ozone, and mercury.

Boreal forest fires in Siberia, Canada, and Alaska represent a major perturbation to the Arctic atmosphere in summer affecting the carbon cycle (Preston and Schmidt, 2006), climate (Amiro et al., 2001), air quality (Colarco et al., 2004), and land ecology (Soja et al., 2007). Long-term records for Canada show an increase in fires over the past 50 years correlated with rising temperatures (Gillett et al., 2004; Girardin, 2007), and this increase is expected to continue as a result of warming (Stocks et al., 1998; Flannigan et al., 2005). Aerosols emitted by the fires could represent a significant forcing or feedback to regional climate change in the Arctic. The summer deployment of ARCTAS focused on better quantifying the fire emissions, the evolution of fire plumes, and the associated radiative effects.

A central motivation for ARCTAS was to enhance the ability of satellite observations of atmospheric composition to address the above issues. Polar-orbiting satellites have unique potential. They observe the long-range transport of mid-latitude pollution to the Arctic. They detect fires and the associated smoke plumes. They measure aerosol optical depths and other aerosol properties, and the concentrations of gas-phase species including ozone, $\mathrm{CO}, \mathrm{NO}_{2}$, and $\mathrm{BrO}$ that are important drivers of Arctic chemistry. Table 1 lists the most important satellite measurements of atmospheric composition during ARCTAS. Observation of the Arctic from space poses unique challenges including bright and cold surfaces, low sun angles, seasonal darkness, and extensive cloud cover. ARCTAS aimed to use aircraft observations to provide the validation, retrieval constraints, correlative data, and process information needed to develop the potential of satellites for Arctic research.

The summer ARCTAS-B deployment was preceded by one week of flights over California sponsored by the California Air Resources Board (CARB) to address regional issues of air quality and climate forcing. Many areas of California exceed the state ozone and fine particulate matter $\left(\mathrm{PM}_{2.5}\right)$ air quality standards, and little improvement in ozone has been observed over the last decade despite continued emission reductions (Cox et al., 2008). Controlling emissions from heavy-duty diesel trucks has been far more difficult than from passenger cars. Shipping emissions have increased. Long-range transport of pollution from Asia or Mexico may be offsetting benefits from local pollution control measures. In addition to these air quality concerns, CARB is embarking on strategies to reduce state greenhouse gas emissions. The ARCTAS-CARB flights focused on collecting data to 
Table 1. Satellite measurements of atmospheric composition during ARCTAS ${ }^{1}$.

\begin{tabular}{|c|c|c|c|}
\hline Instrument (platform, launch year) & Spectral range ${ }^{2}$ & Relevant measurements & Reference \\
\hline GOME-2 (MetOp, 2006) & UV/Vis & $\begin{array}{l}\text { Tropospheric ozone, } \mathrm{BrO}, \mathrm{NO}_{2} \text {, formaldehyde, } \\
\text { glyoxal }\end{array}$ & Munro et al. (2007) \\
\hline CALIOP (Calipso, 2006) & Vis/NIR & Vertical distribution of aerosol optical depth & Winker et al. (2007) \\
\hline OMI (Aura, 2004) & UV/Vis & $\begin{array}{l}\text { Tropospheric ozone, } \mathrm{BrO}, \mathrm{NO}_{2} \text {, formaldehyde, } \\
\text { glyoxal, absorbing aerosol }\end{array}$ & Levelt et al. (2006) \\
\hline TES (Aura, 2004) & TIR & Tropospheric ozone, $\mathrm{CO}$, methane & Worden et al. (2008) \\
\hline MLS (Aura, 2004) & Microwave & Upper tropospheric ozone, $\mathrm{CO}$ & Livesey et al. (2008) \\
\hline MODIS (Aqua, 2002; Terra, 1999) & UV/Vis/NIR & Aerosol optical depth and size classes & Remer et al. (2005) \\
\hline AIRS (Aqua, 2002) & TIR & $\mathrm{CO}$, methane & McMillan et al. (2008) \\
\hline SCIAMACHY (Envisat, 2002) & UV/Vis/NIR & $\begin{array}{l}\text { Tropospheric } \mathrm{BrO}, \mathrm{NO}_{2} \text {, formaldehyde, gly- } \\
\text { oxal, } \mathrm{CO} \text {, methane }\end{array}$ & Sioris et al. (2006) \\
\hline MOPITT (Terra, 1999) & NIR/TIR & $\mathrm{CO}$ & Deeter et al. $(2009,2010)$ \\
\hline MISR (Terra, 1999) & Vis/NIR & Aerosol optical depth, injection heights & Kahn et al. $(2005,2007)$ \\
\hline
\end{tabular}

1 All instruments are on polar-orbiting satellites. The Calipso, Aura, and Aqua satellites are on the A-train orbit with overpass at 13:30 local time (LT); other overpass times are 10:45 LT for Envisat and 10:30 LT for Terra. All instruments observe in the nadir only except MLS (limb) and SCIAMACHY (nadir and limb).

${ }^{2} \mathrm{NIR}=$ near (solar) IR; TIR=thermal IR. All instruments are passive radiometers except CALIOP (active lidar)

aid California improve its emission inventories and air quality models.

\section{ARCTAS scientific themes and mission design}

ARCTAS was organized around four main research themes: (1) long-range transport of pollution to the Arctic, (2) boreal forest fires, (3) aerosol radiative forcing, and (4) ozone budget and chemical processes. We elaborate here on each of these themes and how they defined the objectives and design of the mission. We also discuss the separate California air quality objectives of the ARCTAS-CARB component.

\subsection{Long-range transport of pollution to the Arctic}

Transport of pollution from northern mid-latitudes to the Arctic takes place throughout the year but the processes and source regions vary with season (Shindell et al., 2008). Intense cooling in winter produces a "polar dome" of cold, stable air that shields the Arctic lower troposphere from isentropic transport from lower latitudes (Klonecki et al., 2003). Low-altitude transport from cold northern Eurasia can still take place and provides then the dominant source of pollution measured at the surface (Stohl, 2006). Transport from North America and East Asia takes place mainly at higher altitudes, in particular through warm conveyor belts (WCBs) associated with storm tracks on the east coast of the continents (Stohl, 2001). This cyclonic activity increases from winter to spring, resulting in a springtime peak of sulfate concentrations in the free troposphere (Scheuer et al., 2003). Midlatitude pollution influence over the Arctic still takes place in summer and fall but is diluted by the weaker general circulation and by more efficient photochemical loss and aerosol scavenging (Barrie, 1986; Brock et al., 1989; Klonecki et al., 2003).

Pollution transport to the Arctic in winter-spring is highly layered (Radke et al., 1984; Brock et al., 1989). This layering reflects the stratification of the Arctic atmosphere, the lack of precipitation, and also possibly the local heating by lightabsorbing aerosol (Quinn et al., 2008; Stone et al., 2008). Scavenging of aerosols and other water-soluble species takes place during WCB lifting of air masses, but this scavenging is not complete (Koike et al., 2003; Miyazaki et al., 2003) and preferentially removes sulfate relative to black carbon (BC) (Park et al., 2005).

The long-range transport theme of ARCTAS targeted the following questions:

- What are the transport pathways for different pollutants to the Arctic?

- What are the contributions from different source regions and what are the source-receptor relationships?

Satellites have obvious potential for observing the longrange transport of pollution to the Arctic. This potential is least in the winter when conditions are cold and dark, and when most of the transport takes place at low altitudes under a prevailingly cloudy atmosphere. We chose therefore to focus on spring as holding more promise for satellite observation, and as offering more opportunities to observe the long-range transport from Asia which is likely to grow in the future. Spring is also of more relevance than winter 
for snowmelt and aerosol radiative forcing. Previous springtime aircraft missions to the Arctic included the Arctic Gas and Aerosol Sampling Program (AGASP) in 1983 (Schnell, 1984) and the Tropospheric Ozone Production about the Spring Equinox (TOPSE) experiment in 2000 (Atlas et al., 2003). Further context was provided by previous NASA aircraft campaigns along the Asian Pacific Rim in spring 1994 (PEM-West B; Hoell et al., 1997) and spring 2001 (TRACEP; Jacob et al., 2003), and over the Northeast Pacific and southern Alaska in spring 2006 (INTEX-B; Singh et al., 2009). PEM-West B and TRACE-P observed frequent lifting of Asian pollution in WCBs followed by northeastward transport toward the Arctic in the general direction of Alaska (Fuelberg et al., 2003). This led to the selection of Fairbanks, Alaska as the main operational base for the ARCTASA spring deployment, and an overnight base in Thule, Greenland to achieve broader spatial coverage.

\subsection{Boreal forest fires}

Wildfires in North America and Eurasia are important regional and hemispheric sources of aerosols, tropospheric ozone, and possibly mercury (Lavoue et al., 2000; Turetsky et al., 2006; Generoso et al., 2007; Leung et al., 2007). Fires are particularly active in the boreal forest zone in summer. Buoyancy generated by the fires can result in injection above the boundary layer (Kahn et al., 2008; McMillan et al., 2008) and in extreme cases in the stratosphere (Fromm and Servanckx, 2003). This lifting of emissions has important implications for the transport, evolution, and impacts of the fire plumes (Morris et al., 2006; Turquety et al., 2007; Hyer et al., 2007; Leung et al., 2007).

Emissions from boreal fires depend on burn conditions (Goode et al., 2000; Reid et al., 2005; Preston and Schmidt, 2006). Rapid aerosol evolution takes place in the fresh plumes through particle coagulation and condensation of organic gases, ammonia, and water (Radke et al., 1995; Fiebig et al., 2002; Colarco et al., 2004). This near-field evolution of the fire plumes determines their regional and global radiative impact (Westphal and Toon, 1991; Fiebig et al., 2003). Ozone production takes place in the fresh plumes from the precursor nitrogen oxide $\left(\mathrm{NO}_{\mathrm{x}}\right)$ radicals, though this is limited by conversion to peroxyacetylnitrate (PAN) (Jacob et al., 1992). Subsequent decomposition of PAN as the plumes age and sink yields additional ozone production on the hemispheric scale (Real et al., 2007).

The boreal forest fires theme of ARCTAS targeted the following questions:

- What are the emissions from boreal forest fires, and what is the near-field chemical evolution of the fire plumes?

- What are the optical properties of the aerosols emitted by boreal forest fires, and how do they evolve during aging of the fire plume?
- What are the injection heights of fire emissions and what processes determine these heights?

- What are the implications of boreal forest fires for regional and global atmospheric composition?

Addressing these questions was the principal objective of the ARCTAS-B summer deployment. July was selected to maximize the probability of sampling large fires in boreal North America. The DC- 8 and P-3 aircraft were based in Cold Lake, Alberta $(54 \mathrm{~N}, 110 \mathrm{~W})$, and the B-200 in Yellowknife, Northwest Territories $(62 \mathrm{~N}, 114 \mathrm{~W})$, on the basis of climatological fire data and available facilities. An overnight base in Thule for the DC- 8 was included in the summer deployment to increase spatial coverage and the opportunities for sampling aged biomass burning plumes.

\subsection{Aerosol radiative forcing}

Aerosol radiative forcing, both direct (clear-sky scattering and absorption) and indirect (aerosol effects on clouds), could be an important regional driver of Arctic climate change (Quinn et al., 2008). Major aerosol types include anthropogenic particles associated with Arctic haze (Barrie and Hoff, 1985; Bodhaine et al., 1989; Clarke, 1989), biomass burning particles from both boreal and lower-latitude fires, and mineral dust particles. These different origins can be separated on the basis of chemical, microphysical, and optical aerosol properties (Bergstrom et al., 2007; Clarke et al., 2007). Radiative effects of aerosols vary not only with aerosol composition but also with solar irradiance, surface albedo, and altitude (Pfister et al., 2008; Stone et al., 2008). $\mathrm{BC}$ aerosol deposited on snow has a warming effect and may promote snow and sea ice melting (Clarke and Noone, 1985; Hansen and Nazarenko, 2004; Flanner et al., 2007).

Aerosol optical properties and the resulting radiative forcing evolve with atmospheric aging (Fiebig et al., 2003; Preston and Schmidt, 2006). This has been observed in particular for boreal forest fire plumes in Canada (O'Neill et al., 2002). Anthropogenic Arctic haze has a wide range of ages and scavenging histories, and this is expected in turn to yield a range of optical properties and radiative forcing (Quinn et al., 2007).

The aerosol radiative forcing theme of ARCTAS targeted the following questions:

- What is the regional radiative forcing from Arctic haze and fire plumes?

- How does this forcing evolve during plume aging?

- What are the major sources of BC aerosol to the Arctic?

- How does BC aerosol deposition affect ice albedo?

Characterizing the forcing associated with aerosol layers was the central task of the P-3 aircraft equipped with an 
ensemble of in situ aerosol and radiative observations. Validation and interpretation of the CALIOP satellite observations of altitude-resolved aerosol extinction was a primary charge of the B-200 aircraft equipped with a high spectral resolution lidar (HSRL). During the spring deployment, the B-200 operated out of Barrow, Alaska to coordinate with the Indirect and Semi-Direct Aerosol Campaign (ISDAC) aircraft mission of the US Department of Energy (DOE). ISDAC focused on aerosol-cloud interactions and was centered over the long-term Atmospheric Radiation Measurement (ARM) North Slope of Alaska (NSA) Climate Research Facility (CRF) at Barrow.

\subsection{Ozone budget and chemical processes}

Tropospheric ozone at high northern latitudes shows a pronounced spring maximum (Logan, 1985; Monks, 2000). The TOPSE aircraft campaign over the North American Arctic in February-May 2000 (Atlas et al., 2003) found that this maximum is driven by tropospheric production rather than by stratospheric input, and that the ozone budget in the region largely reflects a balance between in situ production and loss (Browell et al., 2003; Emmons et al., 2003). However, ozonesonde data from Canadian stations show significant stratospheric impact on tropospheric ozone in both spring and summer (Tarasick et al., 2007; Thompson et al., 2007). Stratospheric influence could be important in the upper troposphere where ozone is of most concern as a greenhouse gas, and this influence could increase in the future as stratospheric ozone recovers and the Brewer-Dobson circulation increases due to greenhouse forcing (Shindell et al., 2007). The Canadian ozonesonde data show a decrease in tropospheric ozone in the 1980s followed by an increase since then, for reasons that are unclear (Tarasick et al., 2005; Kivi et al., 2007).

Tropospheric ozone chemistry in the Arctic is largely determined by the supply of hydrogen oxide radicals $\left(\mathrm{HO}_{\mathrm{x}}\right)$ and nitrogen oxide radicals $\left(\mathrm{NO}_{\mathrm{x}}\right)$ but the processes controlling the abundances of these radicals are poorly understood, including the possible role of photochemistry taking place in snow (Grannas et al., 2007). An additional feature of the Arctic boundary layer in spring is the presence of high concentrations of bromine and chlorine radicals produced by photochemical reactions involving sea salt particles deposited on sea ice. High concentrations of bromine radicals in the Arctic boundary layer lead to catalytic destruction of ozone (Barrie et al., 1988) and drive rapid oxidation of elemental mercury to oxidized mercury which is subsequently deposited (Goodsite et al., 2004), resulting in ozone depletion events (ODEs) and mercury depletion events (MDEs) (Simpson et al., 2007b; Steffen et al., 2008). Chlorine atoms can also lead to rapid oxidation of volatile organic compounds (VOCs) (Zeng et al., 2006). Fresh sea ice and ice leads are thought to be preferential environments for generation of halogen radicals (Bottenheim and Chan, 2006; Simpson et al., 2007a), but the ODEs can spread over $1000 \mathrm{~km}$ downwind (Ridley et al., 2003; Zeng et al., 2006). Satellite observations of BrO columns indicate hotspots over the Arctic in spring that have been attributed to the boundary layer (Chance, 1998; Hollwedel et al., 2004) but these observations had not been validated prior to ARCTAS.

The chemical processing theme of ARCTAS targeted the following questions:

- What controls $\mathrm{HO}_{\mathrm{x}}$ and $\mathrm{NO}_{\mathrm{x}}$ chemistry in the Arctic?

- What drives halogen radical chemistry in the Arctic, and what is its regional extent?

- What are the regional implications for ozone, aerosols, and mercury?

- How does stratosphere-troposphere exchange affect tropospheric ozone in the Arctic?

The DC- 8 included a detailed chemical payload to address these questions. One priority was to validate the satellite observations of high $\mathrm{BrO}$ events. These events are most frequent in March-April (Hollwedel et al., 2004). We chose April as more favorable in terms of photochemistry, satellite observation capabilities, and operations weather.

\subsection{California air quality (ARCTAS-CARB)}

The objectives of the California deployment (ARCTASCARB) were to: (1) improve state emission inventories for greenhouse gases and aerosols; (2) characterize offshore emissions of sulfur and other pollutants from shipping and natural sources; and (3) characterize upwind boundary conditions for modeling local surface ozone and $\mathrm{PM}_{2.5}$. Despite extensive abatement efforts, air quality standards are widely exceeded in southern California and the Central Valley (Cox et al., 2008). Little improvement in ozone has been observed in the past decade despite continued reduction in precursor emissions. The causes for this lack of progress are unknown but could reflect poorly understood non-linearities in the photochemical system. There is far more sulfate in southern California than can be accounted for in present emission inventories and ship emissions may be implicated (Spencer et al., 2009). Another issue is the poorly quantified import of pollution from Asia and Mexico (Jacob et al., 1999; Oltmans et al., 2008; Wang et al., 2009). California is now embarking on synergistic strategies to control greenhouse gas emissions together with air pollutants. A first step is to improve inventories for these emissions.

The ARCTAS-CARB flights targeted the following questions:

- How good is our current understanding of the $\mathrm{HO}_{\mathrm{x}}$ $\mathrm{NO}_{\mathrm{x}}-\mathrm{O}_{3}$-aerosol photochemical system over the Los Angeles Basin as represented in air quality models?

- How should upwind boundary conditions for simulating air quality in California be specified? 
Table 2. Operational characteristics of the ARCTAS aircraft.

\begin{tabular}{llll}
\hline & DC-8 & P-3 & B-200 \\
\hline Ceiling, km & 12 & 7 & 9 \\
Ground speed, knots & $240-480$ & $270-330$ & $80-290$ \\
Endurance, h & 10 & 8 & 5 \\
Payload, tons & 20 & 7 & 0.5 \\
\hline
\end{tabular}

- How do ship emissions and long-range transport affect the sulfur budget in southern California?

- What are the state emissions of VOCs and greenhouse gases from urban and industrial activities, agricultural operations, and wildfires?

The flights took advantage of the fully loaded DC- 8 and P-3 aircraft based in California just before the ARCTAS-B summer deployment. In addition to the local air quality objectives, these California flights helped to address the ARCTAS Arctic objectives by providing contrasting data, expanding the ranges of the instruments, and characterizing emissions from California wildfires that would then be sampled as aged plumes from the aircraft based in Canada.

\section{Mission execution}

\subsection{Aircraft payloads and support}

Table 2 gives the characteristics of the DC- $8, \mathrm{P}-3$, and B200 aircraft as used in ARCTAS. Tables $3 a-c$ lists the payloads for each. The DC-8 had the largest range and payload. It was responsible for addressing the long-range transport and chemical processing themes of ARCTAS, and also contributed to the boreal fires theme. Its payload included measurements of ozone (in situ and remote); $\mathrm{HO}_{\mathrm{x}}, \mathrm{NO}_{\mathrm{x}}$, and $\mathrm{BrO}$ radicals; reservoirs for these radicals and related species; aerosols, carbon gases, and mercury; tracers of transport; and actinic fluxes. Measurements of $\mathrm{HO}_{\mathrm{x}}$ radicals were made by two independent techniques (LIF and CIMS), since previous comparisons between data sets and with models in past aircraft missions had been inconsistent (Ren et al., 2008).

The P-3 and B-200 payloads focused on aerosol characterization and radiation, targeting the aerosol radiative forcing theme of ARCTAS and addressing aerosol source issues related to Arctic haze and boreal fires. The P-3 payload included in situ measurements of aerosol properties; solar irradiance and direct-beam transmission measurements; surface reflectivity measurements; and $\mathrm{CO}$ as a pollution tracer. The B-200 payload included a high-spectral resolution lidar (HSRL) and the Research Scanning Polarimeter (RSP), a precursor to the Aerosol Polarimetry Sensor (APS) to be launched on the NASA Glory satellite.
Intercomparisons of instruments were conducted aboard the DC-8 for redundant measurements $\left(\mathrm{HO}_{\mathrm{x}}, \mathrm{NO}_{2}, \mathrm{HNO}_{3}\right.$, oxygenated VOCs, $\mathrm{SO}_{2}$, sulfate). Wingtip-to-wingtip legs involving the DC-8, the P-3, the NOAA WP-3D, and the DLR Falcon were conducted to intercompare instruments across aircraft. Intercomparison results for $\mathrm{H}_{2} \mathrm{O}, \mathrm{O}_{3}, \mathrm{CO}$, $\mathrm{HNO}_{3}, \mathrm{HO}_{\mathrm{x}}$ and $\mathrm{BC}$ are presented by Kleb et al. (2009) and a complete report is available from the Tropospheric Airborne Measurements Evaluation Panel (TAbMEP) at http: //www-air.larc.nasa.gov/TAbMEP.html.

Frequent ozonesonde launches during ARCTAS were made at the 17 sites of the Arctic Intensive Ozonesonde Network Study (ARC-IONS) (Table 3d). The spring sites were chosen to emphasize latitudinal gradients, opportunities to sample Arctic pollution, and coordination with aircraft and ground stations. The summer sites were aligned to capture cross-continental flow. Special launches were timed to coincide with TES satellite instrument overpasses for ozone validation (Boxe et al., 2010).

ARCTAS execution was also supported by ground-based measurements (Table 3e) and various forecasts and analyses (Table 3f). The ground-based measurements included aerosol lidars, sun-sky photometers, in situ measurements from an instrumented trailer, and multi-axis differential optical absorption spectroscopy (MAX-DOAS) measurements of $\mathrm{BrO}$ at Barrow. Meteorological and chemical transport model (CTM) forecasts, near-real-time satellite and CTM data, and fire reports were used to guide flights on a dayto-day basis.

\subsection{Deployments}

The spring ARCTAS-A deployment took place from 1 to 21 April 2008. Flight tracks are shown in Fig. 1a. The DC8 and P-3 were based in Fairbanks $(65 \mathrm{~N}, 148 \mathrm{~W})$ and the B-200 in Barrow (71 N, $157 \mathrm{~W})$. The DC-8 made overnight flights to Thule $(77 \mathrm{~N}, 69 \mathrm{~W})$ and Iqaluit, Nunavut $(64 \mathrm{~N}$, $69 \mathrm{~W}$ ). Iqaluit was used as a contingency airport because of bad weather in Thule on the second planned overnight. The P-3 also made an overnight flight to Thule. Flights were coordinated with the Aerosol, Radiation, and Cloud Processes affecting Arctic Climate (ARCPAC) aircraft mission of the National Oceanic and Atmospheric Administration (NOAA) as well as with the DOE ISDAC aircraft mission, both concurrently based in Fairbanks. ARCPAC focused on the factors determining the radiative forcing by aerosols and tropospheric ozone in the Arctic, dovetailing with the objectives of ARCTAS. It used a WP-3D aircraft with in situ instrumentation for aerosols and clouds, ozone, related species, and radiation. ISDAC focused on aerosol-cloud interactions in the Arctic, including indirect forcing and scavenging processes. It used a Convair-580 aircraft with in situ instrumentation for aerosol and cloud microphysical properties. Flight tracks were mainly to and over the ARM CRF site at Barrow and involved coordination with the B-200. 
Table 3a. DC-8 research payload in ARCTAS.

\begin{tabular}{|c|c|c|c|}
\hline Species, parameters ${ }^{1}$ & Method $^{2}$ & Investigator & Reference \\
\hline $\mathrm{CO}, \mathrm{CH}_{4}, \mathrm{~N}_{2} \mathrm{O}, \mathrm{H}_{2} \mathrm{O}$ & TDLAS & G. Diskin, NASA LaRC & $\begin{array}{l}\text { Sachse et al. (1987), Diskin } \\
\text { et al. (2002) }\end{array}$ \\
\hline $\mathrm{CO}_{2}$ & $\begin{array}{l}\text { Non-dispersive IR an- } \\
\text { alyzer }\end{array}$ & S. Vay, NASA LaRC & Vay et al. (2003) \\
\hline Ozone, $\mathrm{NO}, \mathrm{NO}_{2}, \mathrm{NO}_{\mathrm{y}}$ & Chemiluminescence & A. Weinheimer, NCAR & Weinheimer et al. (1994) \\
\hline $\begin{array}{l}\text { Ozone and aerosol vertical distribution } \\
\text { (remote) }\end{array}$ & DIAL & E. Browell, NASA LaRC & Fenn et al. (1999) \\
\hline $\mathrm{NO}_{2}$, PANs, alkyl nitrates & TD-LIF & R. Cohen, UC Berkeley & Cleary et al. (2002) \\
\hline $\begin{array}{l}\mathrm{HNO}_{3} \text {, soluble } \mathrm{Br} \text {, aerosol ionic compo- } \\
\text { sition }\end{array}$ & mist chamber/IC & J. Dibb, U. New Hampshire & $\begin{array}{l}\text { Scheuer et al. (2003), Mc- } \\
\text { Naughton et al. (2007) }\end{array}$ \\
\hline $\mathrm{HNO}_{3}$, peroxides, $\mathrm{HCN}$, organic acids & CIMS & P. Wennberg, Caltech & Crounse et al. $(2006,2009)$ \\
\hline PANs, $\mathrm{HNO}_{4}, \mathrm{SO}_{2}$, halogens & CIMS & G. Huey, Georgia Tech & $\begin{array}{l}\text { Slusher et al. (2004), Kim et } \\
\text { al. (2007) }\end{array}$ \\
\hline $\mathrm{OH}, \mathrm{HO}_{2}$ & LIF & W. Brune, Penn State & Brune et al. (1999) \\
\hline $\mathrm{OH}, \mathrm{HO}_{2}, \mathrm{RO}_{2}, \mathrm{H}_{2} \mathrm{SO}_{4}$ & CIMS & C. Cantrell, NCAR & Cantrell et al. (2003) \\
\hline $\mathrm{HCHO}$ & TDLAS & A. Fried, NCAR & Fried et al. (2008) \\
\hline NMHCs, halocarbons, alkyl nitrates & WAS-GC & D. Blake, UC Irvine & Blake et al. (2003) \\
\hline NMHCs, OVOCs, halocarbons, $\mathrm{CH}_{3} \mathrm{CN}$ & GC-MS & $\begin{array}{l}\text { E. Apel, NCAR; D. Riemer, U. } \\
\text { Miami }\end{array}$ & Apel et al. (2003) \\
\hline Organic gases & PTR-MS & A. Wisthaler, U. Innsbruck & Wisthaler et al. (2002) \\
\hline $\begin{array}{l}\text { Aerosol number, size distribution, volatil- } \\
\text { ity, optical properties, CCN, EC/OC, } \\
\text { cloud microphysics, LWC }\end{array}$ & $\begin{array}{l}\mathrm{CCN} \text { counter, OPC, } \\
\text { aethelometer, neph- } \\
\text { elometer }\end{array}$ & B. Anderson, NASA LaRC & Anderson et al. (1998) \\
\hline $\begin{array}{l}\text { Size-resolved aerosol composition, } \\
\text { volatility }\end{array}$ & HR-ToF-AMS & J.L. Jimenez, U. Colorado & DeCarlo et al. (2008) \\
\hline $\begin{array}{l}\text { Aerosol inorganic and organic composi- } \\
\text { tion }\end{array}$ & PILS & R. Weber, Georgia Tech & Sullivan et al. (2006) \\
\hline Black carbon aerosol & SP2 & Y. Kondo, U. Tokyo & $\begin{array}{l}\text { Moteki and Kondo (2007, } \\
\text { 2008) }\end{array}$ \\
\hline $\begin{array}{l}\text { Elemental, reactive, and particulate mer- } \\
\text { cury }\end{array}$ & AFS & R. Talbot, U. New Hampshire & Talbot et al. (2008) \\
\hline Actinic fluxes and photolytic frequencies & spectral radiometry & R. Shetter, NCAR & Shetter and Miller (1999) \\
\hline
\end{tabular}

${ }^{1}$ Chemical concentrations unless otherwise indicated. $\mathrm{NO}_{y}=$ total reactive nitrogen oxides, including $\mathrm{NO}_{\mathrm{x}}$ and its oxidation products; PANs $=$ peroxyacylnitrates; $\mathrm{NMHCs}=$ nonmethane hydrocarbons; OVOCs = oxygenated volatile organic compounds; $\mathrm{CCN}=$ cloud condensation nuclei; $\mathrm{EC}=$ elemental carbon; $\mathrm{OC}=$ organic carbon; $\mathrm{LWC}=$ liquid water content.

2 DIAL = Differential Absorption Lidar; TD-LIF = Thermal-Dissociation Laser Induced Fluorescence; CIMS = Chemical Ionization Mass Spectrometry; TDLAS = Tunable Diode Laser Absorption Spectroscopy; WAS-GC = Whole Air Sampling - Gas Chromatography; GC-MS = Gas Chromatography - Mass Spectrometry; PTR-MS = Proton Transfer Reaction -Mass Spectrometry; IC = Ion Chromatography; CCN = cloud condensation nuclei; OPC = Optical Particle Counter; HR-ToF-AMS = High-Resolution Time-of-Flight Aerosol Mass Spectrometer; PILS = Particle Into Liquid Sampler; SP2 = Single Particle Soot Photometer; AFS = Atomic Fluorescence Spectrophotometry.

The summer ARCTAS-B deployment took place from 26 June to 14 July 2008. Flight tracks are shown in Fig. 1 b. The DC-8 and P-3 were based in Cold Lake $(54 \mathrm{~N}, 110 \mathrm{~W})$ and the B-200 in Yellowknife (62 N, $114 \mathrm{~W})$. The DC-8 did a two-night stay in Thule to overfly Summit, Greenland (73 N, 39 W), where the US National Science Foundation (NSF) led an intensive ground-based campaign. The Thule base also offered the opportunity to coordinate flights with the German Deutsches Zentrum fur Luft- und Raumfahrt (DLR) and the French Centre National de Recherche Scientifique (CNRS) aircraft missions based in Kangerlussuaq, Greenland $(67 \mathrm{~N}$,
$51 \mathrm{~W})$. These missions focused on sampling outflow from North American boreal forest fires.

The ARCTAS-CARB deployment took place from 18 to 24 June 2008, immediately preceding ARCTAS-B. Flight tracks are shown in Fig. 1c. The DC-8 conducted four flights $(33 \mathrm{~h})$ from its base in Palmdale, California $(35 \mathrm{~N}, 118 \mathrm{~W})$. The P-3 conducted two flights ( $12 \mathrm{~h}$ ) from its base in Moffett Field, California ( $37 \mathrm{~N}, 122 \mathrm{~W}$ ). Additional data relevant to ARCTAS-CARB objectives were collected during the transit flights to and from Canada. 
Table 3b. P-3 research payload in ARCTAS.

\begin{tabular}{|c|c|c|c|}
\hline Parameters & Method & Investigator & Reference \\
\hline $\begin{array}{l}\text { Aerosol number, size, composition, } \\
\text { volatility, optical properties }\end{array}$ & $\begin{array}{l}\text { OPC, PSAP, TDMA, } \\
\text { CN counter }\end{array}$ & A. Clarke, U. Hawaii & Clarke et al. (2004) \\
\hline $\begin{array}{l}\text { Size-resolved aerosol composition and } \\
\text { volatility, black carbon aerosol, } \\
\text { light scattering }\end{array}$ & ToF-AMS, SP2, nephelometer & Ibid. & $\begin{array}{l}\text { Anderson and Ogren } \\
(1998), \text { Schwarz et } \\
\text { al. (2006), DeCarlo et } \\
\text { al. (2008) }\end{array}$ \\
\hline $\mathrm{CCN}$ & $\mathrm{CCN}$ counter & A. Nenes, Georgia Tech & $\begin{array}{l}\text { Roberts and Nenes } \\
(2005), \text { Lance et } \\
\text { al. (2006) }\end{array}$ \\
\hline Aerosol optical properties & Cavity ring-down extinction & A. Strawa, NASA ARC & Strawa et al. (2006) \\
\hline $\mathrm{AOD}, \mathrm{H}_{2} \mathrm{O}$ column & Tracking Sun photometer & J. Redemann, NASA ARC & Russell et al. (2007) \\
\hline Solar spectral irradiance & Spectrometer & S. Schmidt, U. Colorado & Kylling et al. (2005) \\
\hline $\mathrm{BRDF}$ & CAR & $\begin{array}{l}\text { C. Gatebe, U. Maryland and } \\
\text { NASA GSFC }\end{array}$ & Gatebe et al. (2003) \\
\hline Radiation fluxes & Broadband radiometers & A. Bucholtz, Naval Res. Lab & Bucholtz et al. (2008) \\
\hline Carbon monoxide (CO) & TLAS & J. Podolske, NASA ARC & $\begin{array}{l}\text { Podolske and Lowen- } \\
\text { stein (1993) }\end{array}$ \\
\hline Ozone $\left(\mathrm{O}_{3}\right)$ & TECO Model 49C & A. Clarke, U. Hawaii & $\begin{array}{l}\text { Parrish and Fehsenfeld } \\
\text { (2000) }\end{array}$ \\
\hline
\end{tabular}

1 AOD = aerosol optical depth; BRDF = bidirectional reflectance distribution function; $\mathrm{CCN}=$ cloud condensation nuclei.

2 OPC = Optical Particle Counter; PSAP = Particle Soot Absorption Photometer; CN = condensation nuclei; ToF-AMS $=$ Time of Flight Aerosol Mass Spectrometer; TDMA = Tandem Differential Mobility Analyzer; SP2 = Single Particle Soot Photometer; CAR = Cloud Absorption Radiometer; TLAS = Tunable Laser Absorption Spectroscopy.

Table 3c. B-200 research payload in ARCTAS.

\begin{tabular}{llll}
\hline Parameters (remote sensing) & Method $^{1}$ & Investigator & Reference \\
\hline $\begin{array}{l}\text { Vertical distribution of aerosol properties including extinction at 532 nm, } \\
\text { backscatter and depolarization at } 532 \text { and } 1064 \mathrm{~nm}\end{array}$ & HSRL & R. Ferrare, NASA LaRC & Hair et al. (2008) \\
$\begin{array}{l}\text { Total and linearly polarized reflectance, aerosol and cloud optical prop- } \\
\text { erties (optical depth, size parameters, refractive index) }\end{array}$ & RSP $^{2}$ & B. Cairns, NASA GISS & Waquet et al. (2009) \\
\hline
\end{tabular}

${ }^{1}$ HSRL $=$ High Spectral Resolution Lidar; RSP = Research Scanning Polarimeter

2 Summer campaign only.

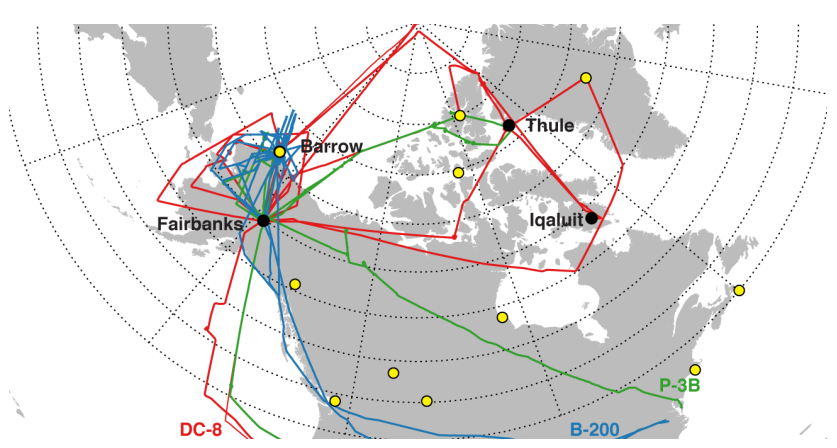

Fig. 1a. Flight tracks for the ARCTAS-A spring deployment (Table $4 \mathrm{a}-\mathrm{c}$ ). Yellow circles are ozonesonde launch sites (Table 3d)

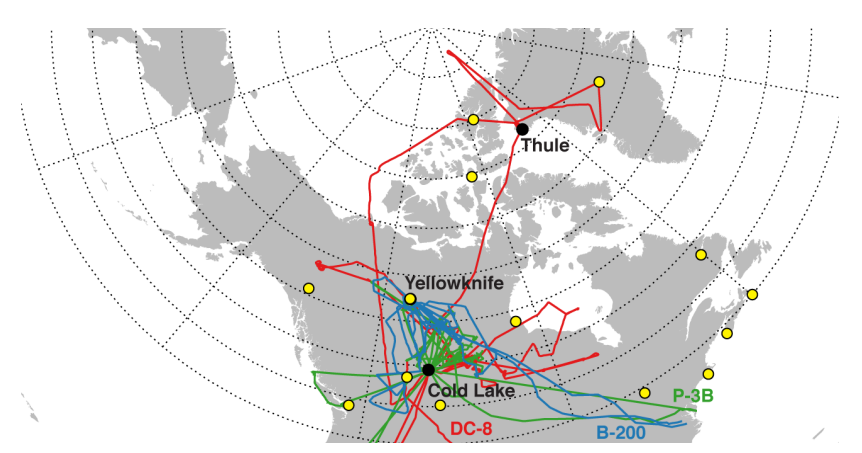

Fig. 1b. Flight tracks for the ARCTAS-B summer deployment (Table $5 \mathrm{a}-\mathrm{c}$ ). Yellow circles are ozonesonde launch sites (Table 3d). 
Table 3d. ARC-IONS ${ }^{1}$ ozonesonde sites during ARCTAS

\begin{tabular}{lll}
\hline Site & Spring launches $^{2}$ & Summer launches $^{3}$ \\
\hline Barrow, Alaska (71 N, 157 W) & 20 & \\
Boulder, Colorado (40 N, 105 W) & & 13 \\
Bratt's Lake, Saskatchewan (50 N, 109 W) & 15 & 13 \\
Churchill, Manitoba (59 N, 94 W) & 17 & 9 \\
Egbert, Ontario (44N, 80W) & & 11 \\
Eureka, Nunavut (80 N, 86 W) & 19 & 1 \\
Goose Bay, Newfoundland (53 N, 60 W) & & 14 \\
Kelowna, British Columbia (49 N, 122 W) & 13 & 13 \\
Narragansett, Rhode Island (41 N, 72 W) & 4 & 3 \\
Resolute, Nunavut (75 N, 95 W) & 17 & 2 \\
Sable Island, Nova Scotia (45 N, 60 W) & 12 & 14 \\
Stony Plain (Edmonton), Alberta (54N, 114W) & 19 & 15 \\
Summit, Greenland (73 N, 39 W) & 19 & 18 \\
Trinidad Head, California (40N, 124W) & 18 & 16 \\
Whitehorse, Yukon Territory (61 N, 135 W) & 12 & 14 \\
Yarmouth, Nova Scotia (44 N, 66 W) & & 19 \\
Yellowknife, Northwest Territories (63 N, 115 W) & & \\
\hline
\end{tabular}

${ }^{1}$ Arctic Intensive Ozonesonde Network Study. Lead investigators were S. Oltmans, NOAA and A. Thompson, Pennsylvania State University.

2 Covering the ARCTAS-A period 1-20 April 2008.

3 Covering the ARCTAS-B period 26 June - 12 July 2008.

Table 3e. Ground-based investigations during ARCTAS.

\begin{tabular}{llll}
\hline Parameters & Method $^{1}$ & Investigator & Reference \\
\hline Remote and in situ measurements & Instrumented trailer & A. Thompson, Penn State & Thompson et al. (2007) \\
Aerosol vertical profiles & Lidar & G. Shaw, UA Fairbanks & Wetzel et al. (2003) \\
AOD and aerosol retrieved properties & Sun and sky photometry & B. McArthur, Environment & Holben et al. (2001) \\
& (AERONET) & Canada; Brent Holben, NASA & \\
Tropospheric BrO & MAX-DOAS & GSFC & Simpson et al. (2007b) \\
\hline
\end{tabular}

${ }^{1}$ MAX-DOAS = Multi-Axis Differential Optical Absorption Spectroscopy, AERONET = Aerosol Robotic Network.

Fuelberg et al. (2010) present a detailed meteorological overview for the ARCTAS periods. There were no major departures from climatology. ARCTAS-A in spring sampled air with a wide range of origins. Cyclone tracks delivering Asian air to the Arctic were shifted northward from their climatological position. Strong mid-latitude cyclonic activity persisted in the summer, transporting Asian pollution and Siberian fire plumes across the Pacific to the west coast of North America. The North Atlantic Oscillation (NAO) was in a negative phase throughout the mission.

Figure 2 shows fire activity during the spring and summer deployments as indicated by MODIS fire counts. April 2008 saw typical seasonal biomass burning in Southeast Asia but unusually early fire activity in eastern Siberia due to low snow cover, and unusually large agricultural burning in Kazakhstan. April 2008 was the second highest fire month in Russia (behind May 2003) over the 2001-2008 duration of the MODIS satellite record (Fisher et al., 2010). Flights from the NOAA ARCPAC mission out of Fairbanks also observed strong and persistent influence from these Russian fires (Warneke et al., 2009).

Summer 2008 saw in general low fire activity in Canada (1.6 Mha burned, as compared to an average of $2.8 \mathrm{Mha}$ for the 1990s, Flannigan et al., 2005) but there was unusually large lightning-generated fire activity in northern Saskatchewan within 1-h flight time from Cold Lake, enabling sampling of fresh fire plumes and their evolution. Burning in northern Saskatchewan was four times the 20year average (Soja et al., 2008). Summer 2008 also saw considerable fire activity in northern California and Siberia, and plumes from these fires were repeatedly sampled by the aircraft. Sessions et al. (2010) simulated the transport of boreal 
Table 3f. Supporting investigations during ARCTAS.

\begin{tabular}{|c|c|c|c|}
\hline Product $^{1}$ & Model, data bases & Investigator & Reference \\
\hline Meteorological forecasts & $\begin{array}{l}\text { Various sources, WRF, WRF- } \\
\text { Chem }\end{array}$ & H. Fuelberg, Florida State U. & Fuelberg et al. (2010) \\
\hline \multicolumn{4}{|l|}{ CTM forecasts } \\
\hline & FLEXPART & J. Burkhart, NILU & Hirdman et al. (2009) \\
\hline & STEM & G. Carmichael, U. Iowa & Adikhary et al. (2008) \\
\hline & GEOS-5 & $\begin{array}{l}\text { J. Rodriguez, NASA GSFC; } \\
\text { D. Jacob, Harvard }\end{array}$ & Liang et al. (2009) \\
\hline & MOZART, CAM-Chem & L. Emmons, NCAR & $\begin{array}{l}\text { Arellano et al. (2007); } \\
\text { Emmons et al. (2010) }\end{array}$ \\
\hline & REAM & Y. Wang, Georgia Tech & Choi et al. (2008) \\
\hline Near-real-time fire data & Various products & M. Fromm, Naval Res. Lab & $\begin{array}{l}\text { Fromm and Servranckx } \\
(2003)\end{array}$ \\
\hline \multicolumn{4}{|l|}{ Near-real-time satellite data } \\
\hline & CALIOP & D. Winker, NASA LaRC & Winker et al. (2007) \\
\hline & OMI & $\begin{array}{l}\text { K. Chance, Harvard- } \\
\text { Smithsonian }\end{array}$ & Levelt et al. (2006) \\
\hline & TES & J. Worden, NASA/JPL & Worden et al. (2008) \\
\hline & AIRS & J. Warner, U. Maryland & McMillan et al. (2008) \\
\hline & MODIS & A. Chu, NASA/GSFC & Chu et al. (2005) \\
\hline & MISR & R. Kahn, NASA/GFSC & Kahn et al. (2005) \\
\hline & MOPITT & L. Emmons, NCAR & Deeter et al. (2010) \\
\hline Emission inventories & Various products & G. Carmichael, U. Iowa & Streets et al. (2006) \\
\hline Photochemical modeling & LaRC box model & J. Olson, NASA LaRC & Olson et al. (2006) \\
\hline Near-real-time global CTM analyses & GEOS-Chem & D. Jacob, Harvard & Zhang et al. (2008) \\
\hline
\end{tabular}

${ }^{1} \mathrm{CTM}=$ chemical transport model

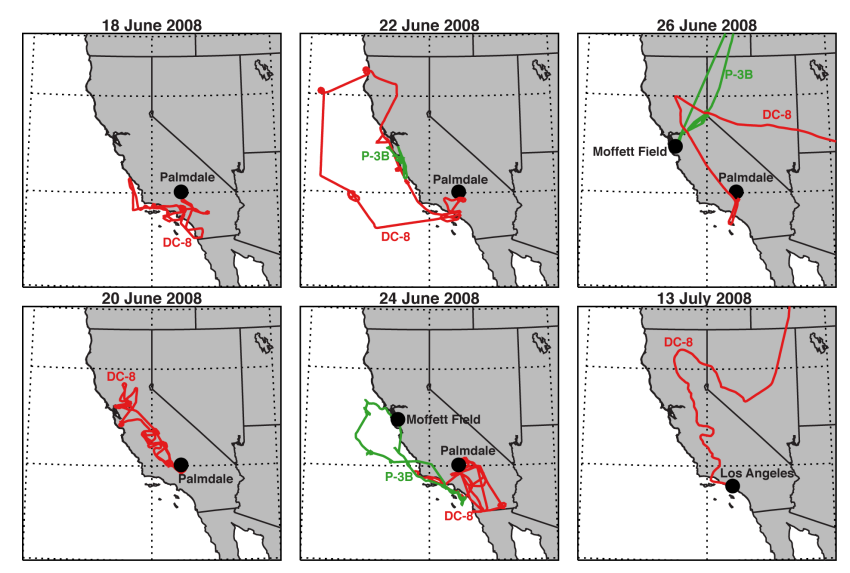

Fig. 1c. Flight tracks for the ARCTAS-CARB deployment (Tables $5 a-b)$.

fire plumes during ARCTAS-B with the WRF-Chem model (Grell et al., 2005) and found that the plume rise parameterization in that model (Freitas et al., 2007) could successfully simulate the injection heights observed from CALIOP and the subsequent long-range transport of smoke and $\mathrm{CO}$ observed from MISR and AIRS.

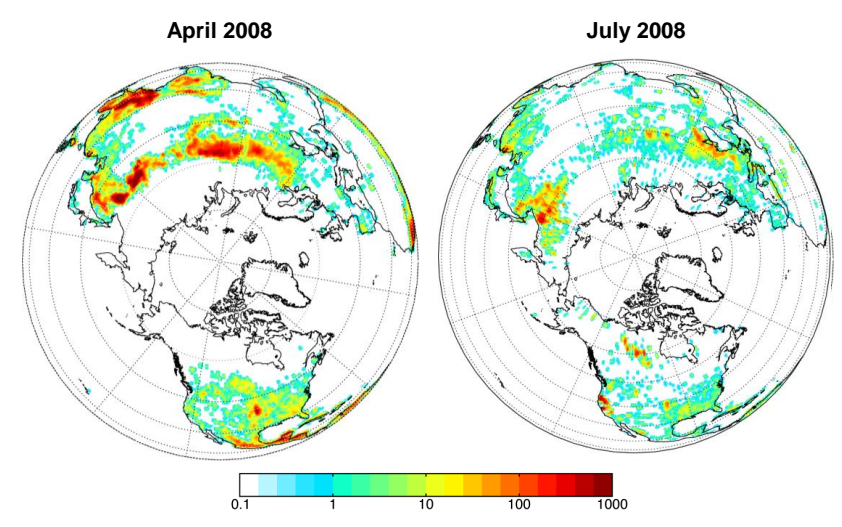

Fig. 2. Monthly fire counts for April and July 2008 from the MODIS Aqua satellite instrument (13:30 local overpass time), cloud- and overpass-corrected (V5, available from http://neespi. gsfc.nasa.gov/myd $14 \mathrm{~cm} 1 . \mathrm{shtml}$ )

Retrievals of CO from the MOPITT instrument on the Terra satellite provide a 9-year record allowing for comparison of 2008 to previous years. Figure 3 shows the monthly anomalies for April and July 2008 (difference between 2008 and the average of corresponding months for 2000-2008). Siberian fires and their outflow across the Pacific stand out in 


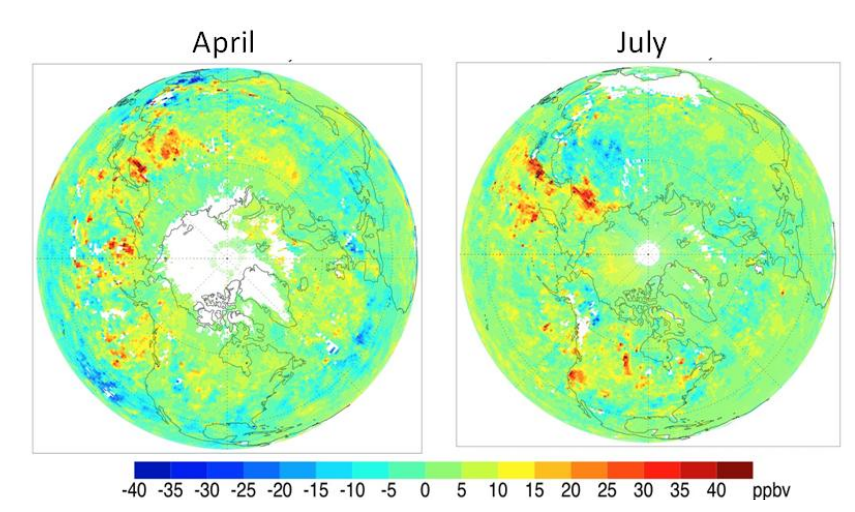

Fig. 3. Monthly mean anomalies of CO column mixing ratios from MOPITT retrievals (V4) for April and July 2008 relative to the 2000-2008 record.

April and remain anomalously high in July. Fires in California and Saskatchewan also stand out in July.

\subsection{Flights}

Tables 4 and 5 lists the research flights of the three aircraft during the spring and summer deployments. ARCTASCARB flights are included in Table 5. The tables describe some specific features of each flight including coordination with other platforms. Coordination between aircraft involved vertically stacked flights to provide complementarity between in situ and remote measurements, and wingtipto-wingtip legs at different altitudes to intercompare instruments. Vertical spirals to complement other measurements were also conducted over several surface sites including Barrow (ARM site, tropospheric BrO), Summit (surface and sondes), and Eureka (vertical column measurements of trace gases). Coordination with satellites involved underpasses and vertical spirals along the satellite orbit tracks. Top priorities were validation of the CALIOP aerosol observations by the B-200 and P-3 aircraft, and of the OMI tropospheric BrO observations by the DC- 8 aircraft.

All flights of the spring ARCTAS-A deployment targeted mid-latitude pollution and fire plumes transported to the Arctic. The P-3 and B-200 focused on aerosol layers. The P-3 also devoted flight time to measuring surface albedo and reflectance, including for sea ice at Elson Lagoon just north of Barrow and over the Arctic ice and clouds near Greenland. The DC- 8 conducted extensive vertical profiling from its nominal floor $(0.15 \mathrm{~km}$ over ocean, $0.3 \mathrm{~km}$ over land) to the stratosphere. To ensure that the boundary layer was properly sampled, the DC- 8 occasionally descended to $0.1 \mathrm{~km}$ over land and made deliberate missed approaches of the Barrow and Prudhoe Bay airports.

All flights of the summer ARCTAS-B deployment targeted wildfire plumes. Again, the P-3 and B-200 focused on aerosol layers. The DC- 8 focused on plume evolution, including sampling of fresh Canadian fire plumes as well as aged Asian and California fire plumes. A few flights sampled plumes from oil sands recovery operations near Fort McMurray in northeast Alberta and found high concentrations of heavy alkanes, aromatics, and $\mathrm{SO}_{2}$ (Simpson et al., 2010). On the outbound flight to Cold Lake, the DC-8 conducted an intercomparison with the NSF HIAPER aircraft as it completed its pre-HIPPO (HIAPER Pole-to-Pole Observations) mission out of Colorado. Pre-HIPPO focused on testing the HIAPER aircraft payload for global observations of greenhouse gases and $\mathrm{BC}$ aerosol. It included several flights to the Arctic in the May-June time frame, bridging the two ARCTAS deployments.

The ARCTAS-CARB flights focused on satellite validation, sampling of emissions, and providing upwind boundary conditions and atmospheric observations to improve air quality models. DC-8 satellite validation focused on TES (ozone, $\mathrm{CO})$, OMI $\left(\mathrm{NO}_{2}\right)$, and MOPITT (CO), while P-3 satellite validation focused on MISR and MODIS (aerosols). Plumes from large wildfires in northern California were repeatedly sampled. These plumes were transported from northern to southern California, allowing opportunities to study their interactions with urban pollution. Extensive low-level sampling was made of emissions from ships, population centers, industrial centers, agricultural crops, feedlots, and dairy farms. Flights also investigated pollution import from Asia and Mexico.

\section{Synthesis of first results}

Interpretation of the ARCTAS data is still in its early stages but promises to successfully address all the mission objectives. Results are already providing important new information on pollution transport and chemistry in the Arctic, its radiative implications, and the utility of satellites for monitoring Arctic atmospheric composition. We summarize here a few highlights.

The ARCTAS observations provided a first validation of satellite observations of atmospheric composition and radiation in the Arctic. Boxe et al. (2010) found that TES V004 retrievals of tropospheric ozone north of $60^{\circ} \mathrm{N}$ during ARCTAS agreed with ARC-IONS ozonesonde profiles within the estimated TES error (15\%), and they reported significant error reduction relative to previous versions of the TES ozone product. Fisher et al. (2010) showed that AIRS daily observations of $\mathrm{CO}$ could successfully track the springtime transport of polluted air masses from mid-latitudes to the Arctic in the free troposphere. Lyapustin et al. (2010) validated the airborne measurements of the bidirectional reflectance distribution function (BRDF) of snow against ground observations, and used them to construct an improved snow BRDF model for satellite retrievals. Extensive data on aerosol optical properties and correlation length scales for biomass burning plumes were obtained to assist satellite AOD retrievals (Shinozuka et al., 2010). Gatebe et al. (2010) used measurements 
Table 4a. DC-8 flights during the ARCTAS-A spring deployment ${ }^{1}$.

\begin{tabular}{|c|c|c|c|}
\hline Flight \# & Location $^{2}$ & Date & Special features \\
\hline 3 & Palmdale-Fairbanks & 1 April & TES and MLS validation, Asian plume \\
\hline 4 & Fairbanks-Thule & 4 April & OMI BrO validation \\
\hline 5 & Thule-Fairbanks & 5 April & Summit spiral, OMI BrO validation, North American plume \\
\hline 6 & Fairbanks-Iqaluit & 8 April & $\begin{array}{l}\text { Prudhoe Bay overpass, intercomparison with } \mathrm{P}-3 \text {, spiral over Eureka, OMI BrO } \\
\text { validation }\end{array}$ \\
\hline 7 & Iqaluit-Fairbanks & 9 April & OMI BrO validation, coordination with B-200, Barrow missed approach ${ }^{3}$ \\
\hline 8 & Fairbanks local 1 & 12 April & Asian plume, Barrow missed approach, NOAA WP-3D intercomparison \\
\hline 9 & Fairbanks local 2 & 16 April & Asian plume, coordination with B-200 \\
\hline 10 & Fairbanks local 3 & 17 April & $\begin{array}{l}\text { N. Pole flight, Asian and European plumes, Prudhoe Bay missed approach, exten- } \\
\text { sive boundary layer ODEs }\end{array}$ \\
\hline 11 & Fairbanks-Palmdale & 19 April & MLS/CALIPSO underflights, P-3 intercomparison, Asian plume \\
\hline
\end{tabular}

${ }^{1}$ Flights were typically $8 \mathrm{~h}$ in duration.

2 Palmdale, California ( $35 \mathrm{~N}, 118 \mathrm{~W}$ ) was the aircraft home base.

3 "Missed approach" refers to an airport runway approach with re-climb just before landing, thus allowing vertical profiling down to the ground.

Table 4b. P-3 flights during the ARCTAS-A spring deployment ${ }^{1}$.

\begin{tabular}{|c|c|c|c|}
\hline Flight \# & Location $^{2}$ & Date & Special features \\
\hline 4 & Yellowknife-Fairbanks & 1 April & Pollution layers, spiral and legs under CALIPSO and OMI. \\
\hline 6 & Fairbanks-Thule & 8 April & $\begin{array}{l}\text { DC- } 8 \text { intercomparison, spiral over Eureka during CALIPSO and OMI overpasses, } \\
\text { BRDF and albedo }\end{array}$ \\
\hline 8 & Fairbanks local 2 & 13 April & Cloud albedo and BRDF, Asian pollution \\
\hline 9 & Fairbanks local 3 & 15 April & $\begin{array}{l}\text { Intercomparison and radiation stack with NOAA P-3 under B-200, BRDF and albedo } \\
\text { at Elson Lagoon, } 6 \text { special albedo sites, zero ozone over open leads, radiation leg on } \\
\text { CALIPSO and OMI track. }\end{array}$ \\
\hline 10 & Fairbanks-Moffett Field & 19 April & $\begin{array}{l}\text { DC-8 intercomparison on CALIPSO and OMI track, steps in DC-8 lidar curtain, } \\
\text { square spiral during CALIPSO and OMI overpass. }\end{array}$ \\
\hline
\end{tabular}

${ }^{1}$ Flights were typically $8 \mathrm{~h}$ in duration.

${ }^{2}$ Wallops, Virginia (38N, 75W), and Moffett Field, California (37N, 122W) were the aircraft home bases.

${ }^{3}$ Sea ice expanse just north of Barrow.

by the P-3 and AERONET near Barrow, Alaska to demonstrate a new method for simultaneously retrieving aerosol and surface properties from combined airborne and groundbased direct and diffuse radiometric measurements.

Total column BrO was measured by both OMI and GOME-2 during ARCTAS. The two satellite instruments showed similar patterns and magnitudes of $\mathrm{BrO}$ hotspots over the Arctic in spring (enhancements of 2 to $3 \times 10^{13} \mathrm{~cm}^{-2}$ relative to the zonal mean). Validation by the aircraft showed that previous attribution of these hotspots to the boundary layer is incorrect. The aircraft revealed both false positives, where hotspots seen from space were not associated with measurable boundary layer $\mathrm{BrO}$, and false negatives, where aircraft observations of elevated boundary layer $\mathrm{BrO}$ (and associated ODEs and MDEs) were not associated with elevated column BrO. False negatives could be due to cloud cover shielding boundary layer $\mathrm{BrO}$ from detection by satellite. As to the false positives, Salawitch et al. (2010) showed that numerous $\mathrm{BrO}$ hotspots observed from space correspond to tropopause depressions, and hypothesized that the elevated $\mathrm{BrO}$ actually resides in the lower stratosphere. Free tropospheric $\mathrm{BrO}$ enhancements above the boundary layer large 
Table 4c. B-200 flights during the ARCTAS-A spring deployment ${ }^{1}$.

\begin{tabular}{|c|c|c|}
\hline Location & Date & Special features \\
\hline Barrow local 2 & 4 April & Coordinated pattern with DOE Convair-580, multiple passes over Barrow ARM site \\
\hline Barrow local 4 & 8 April & $\begin{array}{l}\text { Two flights coordinated with DOE Convair-580, extensive low cloud over Barrow, aerosol layers } \\
\text { aloft }\end{array}$ \\
\hline Barrow local 5 & 9 April & $\begin{array}{l}\text { CALIPSO validation over W Alaska, coordinated flight with DC-8 under CALIPSO track and } \\
\text { near Barrow }\end{array}$ \\
\hline Barrow local 7 & 12 April & $\begin{array}{l}\text { Coordinated CALIPSO track with DC- } 8 \text { and NOAA WP-3D SW of Barrow, biomass burning } \\
\text { plumes }\end{array}$ \\
\hline Barrow-Fairbanks & 13 April & $\begin{array}{l}\text { Coordinated CALIPSO track with P-3 over W Alaska, coordination with DOE Convair-580 near } \\
\text { Barrow }\end{array}$ \\
\hline Fairbanks local & 15 April & $\begin{array}{l}\text { Coordination with P-3 and NOAA P-3 west of Fairbanks and with CALIPSO track over central } \\
\text { Alaska, biomass burning plumes }\end{array}$ \\
\hline
\end{tabular}

${ }^{1}$ Flights were typically $5 \mathrm{~h}$ in duration.

Table 5a. DC-8 flights during the ARCTAS-B summer deployment ${ }^{1}$.

\begin{tabular}{|c|c|c|c|}
\hline Flight \# & Location & Date & Special features \\
\hline 12 & Palmdale local 1 & 18 June & Los Angeles Basin and offshore ship emissions \\
\hline 13 & Palmdale local 2 & 20 June & California Central valley, sampling of urban and biogenic source regions \\
\hline 14 & Palmdale local 3 & 22 June & California upwind boundary conditions \\
\hline 15 & Palmdale local 4 & 24 June & Los Angeles Basin diurnal evolution and offshore ship emissions \\
\hline 16 & Palmdale-Cold Lake & 26 June & California fire plumes, OMI validation, HIAPER intercomparison \\
\hline 17 & Cold Lake local 1 & 29 June & Siberian fire plume, pyroconvective outflow, Saskatchewan fires \\
\hline 18 & Cold Lake local 2 & 1 July & $\begin{array}{l}\text { Detailed characterization of Saskatchewan fire plumes over aging times rang- } \\
\text { ing from minutes to hours }\end{array}$ \\
\hline 19 & Cold Lake local 3 & 4 July & $\begin{array}{l}\text { Near-field evolution of Saskatchewan fire plumes, California and Siberian fire } \\
\text { plumes, deep convective injection of smoke and biogenic VOCs, TES valida- } \\
\text { tion }\end{array}$ \\
\hline 20 & Cold Lake local 4 & 5 July & Saskatchewan fire plumes, biogenic emissions \\
\hline 21 & Cold Lake-Thule & 8 July & Siberian fires and Asian pollution \\
\hline 22 & Thule local & 9 July & $\begin{array}{l}\text { MOPITT validation over Summit, intercomparison with DLR Falcon, Siberian } \\
\text { fires and Asian pollution }\end{array}$ \\
\hline 23 & Thule-Cold Lake & 10 July & P-3 intercomparison, oil sands plumes \\
\hline 24 & Cold Lake-Los Angeles & 14 July & California fire plumes \\
\hline
\end{tabular}

${ }^{1}$ Flights $12-15$ were part of the ARCTAS-CARB deployment. Flight durations were typically $8 \mathrm{~h}$.

were also observed during ARCTAS-A and ARCPAC (Neuman et al., 2010). Closure of the budget for total column BrO observed from space could be achieved by assuming that short-lived biogenic bromocarbons supply 5 to $10 \mathrm{ppt}$ of inorganic bromine $\left(\mathrm{Br}_{\mathrm{y}}\right)$ to the stratosphere (Salawitch et al., 2010). This supply of $\mathrm{Br}_{\mathrm{y}}$ is higher than simulated in current models and may have important consequences for the photochemical budget of ozone in the upper troposphere and lower stratosphere.

The April ARCTAS flights did find extensive ODEs and MDEs in the Arctic boundary layer associated with high concentrations of halogen radicals (Koo et al., 2009; Mao et 
Table 5b. P-3 flights during the ARCTAS-B summer deployment ${ }^{1}$.

\begin{tabular}{|c|c|c|c|}
\hline Flight \# & Location & Date & Special features \\
\hline 11 & Moffett Field local 1 & 22 June & $\begin{array}{l}\text { Power plant plume, BRDF circles, ship plume, AERONET-lidar-Terra com- } \\
\text { parisons, wildfire smoke }\end{array}$ \\
\hline 12 & Moffett Field local 2 & 24 June & $\begin{array}{l}19 \text { ship plume crossings, profiles under Terra and Aqua, ocean BRDF (calm \& } \\
\text { 50-knot winds), ship wake radiative effects, fire and pollution plumes }\end{array}$ \\
\hline $13 / 14^{2}$ & Moffett Field-Cold Lake & 26 June & $\begin{array}{l}\text { Lake Tahoe smoke radiation study in DC- } 8 \text { lidar curtain and under Terra, lake } \\
\text { albedo and BRDF, Central Valley smoke gradient }\end{array}$ \\
\hline 15 & Cold Lake local 1 & 28 June & Fresh fire plumes (including pyrocumulus), coordination with B-200 \\
\hline 16 & Cold Lake local 2 & 29 June & Fresh fire plumes, oil sands plume, BRDF and albedo over lake and land \\
\hline 17 & Cold Lake local 3 & 30 June & $\begin{array}{l}\text { CALIPSO, MODIS, and OMI underflight, black and white smoke, in situ and } \\
\text { radiation under B-200, BRDF over smoke, smoke radiative forcing efficiency, } \\
\text { Asian pollution with dust }\end{array}$ \\
\hline 18 & Cold Lake local 4 & 2 July & Radiation work under B-200, aerosol evolution in fire plumes, pyrocumulus \\
\hline 19 & Cold Lake local 5 & 3 July & $\begin{array}{l}\text { Ft. McMurray AERONET spiral in regional fire haze, MODIS-MISR- } \\
\text { MOPITT spiral, B-200 and CALIPSO-OMI underpass spiral, radiation stack, } \\
\text { forest BRDF, fresh fire plumes and downwind evolution, radiation-AOD-in } \\
\text { situ ramp. }\end{array}$ \\
\hline 20 & Cold Lake local 6 & 6 July & $\begin{array}{l}\text { Radiation profiles and legs under MODIS and MISR, BRDF of water surfaces, } \\
\text { cloud edges and dense smoke spirals under B-200, pyrocumulus outflow }\end{array}$ \\
\hline 21 & Cold Lake local 7 & 7 July & $\begin{array}{l}\text { Siberian fire plume, aerosol effects on MODIS cloud sensing, radiation stacks, } \\
\text { circles and spiral over AERONET site }\end{array}$ \\
\hline 22 & Cold Lake local 8 & 9 July & $\begin{array}{l}\text { Spirals and radiation legs under MISR, radiation legs and stacks in fresh fire } \\
\text { plumes under B-200 and CALIPSO-OMI }\end{array}$ \\
\hline 23 & Cold Lake local 9 & 10 July & Fresh fire plumes, Ft. McMurray plume, DC-8 intercomparison under B-200 \\
\hline 24 & Cold Lake-Wallops & 14 July & Transit \\
\hline
\end{tabular}

${ }^{1}$ Flight 12 was part of the ARCTAS-CARB deployment. Flight durations were typically $8 \mathrm{~h}$.

${ }^{2}$ Flight 13 was from Moffett Field to Edmonton, Alberta (Canadian customs) and flight 14 was from Edmonton to Cold Lake.

Table 5c. B-200 flights during the ARCTAS-B summer deployment ${ }^{1}$.

\begin{tabular}{lll}
\hline Location & Date & Special features \\
\hline Yellowknife local 1 & 28 June & CALIPSO validation track, coordination with P-3 over Saskatchewan fires \\
Yellowknife local 2 & 29 June & Coordination with DC-8 over Saskatchewan fires and smoke plumes \\
Yellowknife local 3 & June & $\begin{array}{l}\text { CALIPSO validation and coordination with P-3 to study Saskatchewan fire } \\
\text { plumes }\end{array}$ \\
Yellowknife local 4 & 2 July & $\begin{array}{l}\text { Two flights; coordination with P-3 over fresh and aged fire plumes; CALIPSO } \\
\text { validation on second flight }\end{array}$ \\
Yellowknife local 5 & 3 July & CALIPSO validation and P-3 coordination along CALIPSO track \\
Yellowknife local 6 & 6 July & $\begin{array}{l}\text { Two flights; second flight was coordination with P-3 for fires and plumes } \\
\text { Yellowknife-Cold Lake-Edmonton }\end{array}$ \\
7 July & $\begin{array}{l}\text { Two flights: Asian/Siberian plume over Alberta } \\
\text { 8 July }\end{array}$ & $\begin{array}{l}\text { Two flights: Asian/Siberian plume over western Alberta/eastern British } \\
\text { Columbia; CALIPSO validation over northern Alberta }\end{array}$ \\
Yellowknife local 7 & 9 July & $\begin{array}{l}\text { CALIPSO validation, coordination with P-3 along CALIPSO track and in } \\
\text { fresh fire plumes }\end{array}$ \\
Yellowknife local 8 & 10 July & CALIPSO validation, coordination with P-3 and DC-8 near Yellowknife \\
\hline
\end{tabular}

${ }^{1}$ Flight durations were typically $5 \mathrm{~h}$. 
al., 2010). These events were mainly confined below $1 \mathrm{~km}$ and did not extend to the free troposphere. Major ODE regions were identified in the Canadian archipelago and north of Alaska and Siberia (Koo et al., 2009). Mercury depletion in these events was consistent with oxidation of elemental $\mathrm{Hg}$ by $\mathrm{Br}$ atoms (Kim et al., 2010).

The ARCTAS observations in April revealed a pervasive background of Asian pollution through the depth of the Arctic tropospheric column, apparently reflecting large-scale accumulation during the dark winter months. Asian pollution influence was strongest in the middle troposphere $(2-6 \mathrm{~km})$. Pollution plumes from all three mid-latitude continents as well as from Siberian fires were superimposed on this elevated background (Table 4 and Fisher et al., 2010). The plumes were relatively dilute: the maximum $\mathrm{CO}$ concentration observed from the DC- 8 during ARCTAS-A north of $55^{\circ} \mathrm{N}$ was $296 \mathrm{ppbv}$. From a model analysis of the aircraft CO data, Fisher et al. (2010) found a general dominance of Asian pollution over the Arctic in spring, except below $2 \mathrm{~km}$ where European pollution influence was of comparable magnitude. North American pollution influence was relatively small. Siberian fire plumes were often transported to the Arctic together with Asian pollution in WCBs but made relatively little contribution to the budget of $\mathrm{CO}$ because of the dominance of accumulated pollution during the winter months. Fisher et al. (2010) found from the multiyear AIRS record that $\mathrm{CO}$ in the North American Arctic was lower than average in spring 2008, despite the large Siberian fires, due to a weak Aleutian Low hindering WCB transport from Asia.

The Siberian fires in spring 2008 had a large effect on carbonaceous aerosols in the Arctic. They were the main source of organic aerosol during ARCTAS-A (Warneke et al., 2009; Wang et al., 2009) and affected the entire Arctic (Saha et al., 2010). Fuel combustion and Siberian fires made contributions of comparable magnitude to the $\mathrm{BC}$ aerosol concentrations over the Arctic during ARCTAS-A (Wang et al., 2009). Combined measurements of multi-wavelength aerosol extinction, aerosol mass spectrometry, and $\mathrm{BC}$ incandescence on the P-3 in ARCTAS-A indicate that aerosols below $2 \mathrm{~km}$ altitude were mainly anthropogenic, whereas those at $2-4 \mathrm{~km}$ altitude were mainly from biomass burning (Shinozuka et al., 2010).

Aircraft measurements of total $\mathrm{NO}_{\mathrm{y}}$ showed good closure with measurements of individual $\mathrm{NO}_{\mathrm{y}}$ components, with PAN the dominant contributor to $\mathrm{NO}_{\mathrm{y}}$ in both spring and summer (Singh et al., 2010). Independent measurements of OH by LIF and CIMS aboard the DC- 8 aircraft showed a median ratio $[\mathrm{OH}]_{\mathrm{LIF}} /[\mathrm{OH}]_{\mathrm{CIMS}}=0.73$, within the stated accuracy of the instruments, and a correlation coefficient $r=0.51$ (Chen et al., manuscript in preparation, 2010). Mao et al. (2010) found that the measured $\mathrm{HO}_{\mathrm{x}}$ and $\mathrm{H}_{2} \mathrm{O}_{2}$ concentrations in spring were significantly lower than predicted from a standard gas-phase mechanism, and hypothesized that this could reflect $\mathrm{HO}_{2}$ radical uptake by aerosol leading to non-radical products other than $\mathrm{H}_{2} \mathrm{O}_{2}$. This heterogeneous chemistry would be particularly important in Arctic spring because of the cold temperatures, relatively high aerosol concentrations, and weak radiation.

Boreal and California forest fire plumes sampled during the summer phase showed similar emission factors and plume optical properties (Singh et al., 2010). $\mathrm{NO}_{\mathrm{x}}$ emission ratios were much lower than literature values for boreal forest fires (Nance et al., 1993; Goode et al., 2000), and rapid conversion of $\mathrm{NO}_{\mathrm{x}}$ to PAN in the fresh plumes further suppressed ozone production (Alvarado et al., 2010; Hecobian et al., 2010). No significant ozone or secondary aerosol production was observed in the fire plumes sampled in summer (Alvarado et al., 2010; Hecobian et al., 2010; Singh et al., 2010), although California fire plumes mixed with urban pollution produced some very high ozone levels (Singh et al., 2010). By contrast, significant ozone enhancements were observed in the aged Siberian fire plumes sampled in spring (Singh et al., 2010). Oltmans et al. (2010) found that tropospheric ozone levels were generally elevated over the west coast of North America in spring 2008, with Denali National Park in Alaska recording an 8-h average maximum value of $75 \mathrm{ppbv}$. They attributed this ozone enhancement to Siberian fire influence.

Methane observations during ARCTAS-A showed little variability and no indication of significant April emissions from Arctic ecosystems. The July observations in ARCTASB showed large emissions from the Hudson Bay Lowlands (HBL), one of the largest boreal wetland ecosystems in the world. Pickett-Heaps et al. (2009) combined the aircraft vertical profiles over the HBL from ARCTAS-B and preHIPPO, together with surface data, to infer a methane emission of $2.7 \mathrm{Tg} \mathrm{a}^{-1}$ from the HBL, much higher than previously estimated values of $0.2-0.5 \mathrm{Tg} \mathrm{a}^{-1}$ (Roulet et al., 1994; Worthy et al., 2000). Singh et al. (2010) found from analysis of ARCTAS-CARB data that methane emissions in California are substantially underestimated in current inventories.

\section{Conclusions}

The ARCTAS mission offers a rich data set for better understanding of Arctic pollution including long-range transport, boreal forest fires influences, aerosol radiative forcing, and chemical processes. It should also be of value as a baseline against which to measure future change. All ARCTAS data are publicly available from http://www-air.larc. nasa.gov/missions/arctas/arctas.html.

Although the ARCTAS deployments covered only two 3week periods in April and June-July 2008, the conditions encountered were highly favorable for addressing mission objectives. The aircraft observed springtime pollution transport events from Asia, North America, and Europe, springtime fire plumes from Siberia, and summertime fire plumes from Canada, California, and Siberia. They encountered a number of boundary layer ozone depletion events in the spring. 
Unusually large fire activity in northern Saskatchewan during the summer deployment allowed detailed study of fire emissions and the near-field evolution of fire plumes.

A central objective of ARCTAS was to increase the value of satellite observations of Arctic atmospheric composition. Validation from the aircraft showed that thermal IR satellite measurements of tropospheric ozone from TES and CO from AIRS are of sufficient quality to track pollution plumes and construct regional budgets. Satellite observations of $\mathrm{BrO}$ column hotspots in spring were shown not to be due to Arctic boundary layer events but instead to tropopause depressions, implying higher inorganic bromine levels in the lower stratosphere (5-10 pptv) than previously thought.

The ARCTAS-A observations showed pervasive Asian pollution influence throughout the Arctic troposphere in spring. There was also significant European pollution influence below $2 \mathrm{~km}$. North American pollution influence was relatively small. Siberian fires were unusually active during April 2008 and greatly enhanced organic aerosol concentrations over the scale of the Arctic. BC aerosol had significant contributions from both fuel combustion and Siberian fires. The Siberian fires also appeared to be responsible for elevated tropospheric ozone over the west coast of North America. $H_{\mathrm{x}}$ measurements from the aircraft by two different methods showed good consistency and lower values in spring than predicted from a gas-phase photochemical model. A possible explanation is uptake of $\mathrm{HO}_{2}$ by aerosols, which would be particularly favored under Arctic springtime conditions.

The ARCTAS-B and ARCTAS-CARB observations showed no significant ozone or secondary aerosol production in plumes from California and boreal fires. However, fast ozone production was observed in California when the fire plumes mixed with urban pollution. Flights over the Hudson Bay Lowlands revealed higher wetland emissions of methane than previously recognized, and flights over California indicated an underestimate of methane emissions in state inventories.

Acknowledgements. This work was funded by the NASA Global Tropospheric Chemistry Program, the NASA Radiation Sciences Program, and the California Air Resources Board. We thank Kelly Chance, Charles Gatebe, and Ross Salawitch for useful comments.

Edited by: A. Stohl

\section{References}

Adhikary, B., Kulkami, S., Dallura, A., et al. : A regional scale chemical transport modeling of Asian aerosols with data assimilation of AOD observations using optimal interpolation technique, Atmos. Environ., 37, 8600-8615, 2008.

Alvarado, M. J., Logan, J. A., Mao, J., et al.: Nitrogen oxides and PAN in plumes from boreal fires during ARCTAS-B and their impact on ozone: An integrated analysis of satellite and aircraft observations, submitted, Atmos. Chem. Phys., 2010.
Anderson, T. L. and Ogren, J. A.: Determining aerosol radiative properties using the TSI 3563 integrating nephelometer, Aerosol Sci. Technol., 29, 57-69, 1998.

Anderson, B. E., Cofer, W. R., Bagwell, D. R., et al.: Airborne observations of aircraft aerosol emissions 1: total nonvolatile particle emission indices, Geophys. Res. Lett., 25, 1689-1692, 1998.

Amiro, B. D., Todd, J. B.,Wotton, B. M., Logan, K. A., Flannigan, M. D., Stocks, B. J., Mason, J. A., Martell, D. L., and Hirsch, K. G.: Direct carbon emissions from Canadian forest fires, 19591999, Can. J. Forest Res. 31, 512-525, 2001

Apel, E. C, Hills, A. J., Lueb, R., Zindel, S., Eisele, S., and Riemer, D. D.: A fast-GC/MS system to measure C-2 to C-4 carbonyls and methanol aboard aircraft, J. Geophys. Res., 108, 8794, doi: 10.1029/2002JD003199, 2003.

Arellano Jr., A. F., Raeder, K., Anderson, J. L., Hess, P. G., Emmons, L. K., Edwards, D. P., Pfister, G. G., Campos, T. L., and Sachse, G. W.: Evaluating model performance of an ensemblebased chemical data assimilation system during INTEX-B field mission, Atmos. Chem. Phys., 7, 5695-5710, doi:10.5194/acp7-5695-2007, 2007.

Atlas, E. L., Ridley, B. A., and Cantrell, C. A.: The Tropospheric Ozone Production about the Spring Equinox (TOPSE) experiment: introduction. J. Geophys. Res., 108, 8353, doi:10.1029/2002JD003172, 2003.

Barrie, L. A.: Arctic air pollution: and overview of current knowledge, Atmos. Environ., 20, 643-663, 1985.

Barrie, L. A., and Hoff, R. M: Five years of air chemistry observations in the Arctic, Atmos. Environ., 19, 1995-2010, 1985.

Barrie, L. A., Bottenheim, J. W., Schnell, R. C., Crutzen, P. J., and Rasmussen, R. A.: Ozone destruction and photochemical reactions at polar in the lower Arctic atmosphere, Nature, 334, 138141, 1988.

Bergstrom, R. W., Pilewskie, P., Russell, P. B., Redemann, J., Bond, T. C., Quinn, P. K., and Sierau, B.: Spectral absorption properties of atmospheric aerosols, Atmos. Chem. Phys., 7, 5937-5943, doi:10.5194/acp-7-5937-2007, 2007.

Blake, N. J., Blake, D. R., Simpson, I. J., et al: NMHCs and halocarbons in Asian continental outflow during the Transport and Chemical Evolution over the Pacific (TRACE-P) field campaign: comparison with PEM-West B, J. Geophys. Res., 108, 8806, doi:10.1029/2002JD003367, 2003.

Bodhaine, B. A., Dutton, E. G., DeLuisi, J. J, Herbert, G. A., Shaw, G. E., and Hansen, A. D. A.: Surface aerosol measurements at Barrow during AGASP II, J. Atmos. Chem., 9, 213-224, 1989.

Bottenheim, J. W., and Chan, E.: A trajectory study into the origin of spring time Arctic boundary layer ozone depletion, J. Geophys. Res., 111. D19301, doi:10.1029/2006JD007055, 2006.

Boxe, C.S., Worden, J.R., Bowman, K.W., et al.: Validation of northern latitude Tropospheric Emission Spectrometer stare ozone profiles with ARC-IONS sondes during ARCTAS, submitted to Atmos. Chem. Phys.

Brock, C. A., Radke, L.F., Lyons, J. H., and Hobbs, P. V. : Arctic hazes in summer over Greenland and the North American Arctic, I, Incidence and origins, J. Atmos. Chem. 9, 129-148, 1989.

Browell, E. V., Hair, J. W., Butler, C. F., et al.: Ozone, aerosol, potential vorticity, and trace gas trends observed at high-latitudes over North America from February to May 2000. J. Geophys. Res., 108, 8369, doi:10.1029/2001JD001390, 2003.

Brune, W. H., Tan, D., Faloona, I. F., et al.: $\mathrm{OH}$ and $\mathrm{HO}_{2}$ chemistry 
in the North Atlantic free troposphere, Geophys. Res. Lett., 26, 3077-3080, 1999.

Bucholtz, A., Bluth, R. T., and Kelly, B.: The Stabilized Radiometer Platform ( STRAP)-An Actively Stabilized Horizontally Level Platform for Improved Aircraft Irradiance Measurements, J. Atmos. Ocean Technol., 25, 2161-2175, 2008.

Cantrell, C. A., Edwards, G. D., Stephens, S., et al.: Peroxy radical behavior during the Transport and Chemical Evolution over the Pacific (TRACE-P) campaign as measured aboard the NASA P-3B aircraft (2003), J. Geophys. Res., 108, 8797, doi:10.1029/2002JD002715, 2003.

Chance, K.: Analysis of BrO measurements from the Global Ozone Monitoring Experiment, Geophys. Res. Lett., 25, 3335-3338, 1998.

Choi, Y., Wang, Y., Zeng, T., Cunnold, D., Yang, E.-S., Martin, R., Chance, K., Thouret, V., and Edgerton, E.: Springtime transitions of $\mathrm{O}_{3}, \mathrm{NO}_{2}$, and $\mathrm{CO}$ over North America: Model evaluation and analysis, J. Geophys. Res., 113, D20311, doi:10.1029/2007JD009632, 2008.

Christensen, J. H., Hewitson, B., Busuioc, A., et al.: Regional Climate Projections, in: Climate Change 2007: The Physical Science Basis. Contribution of Working Group I to the Fourth Assessment Report of the Intergovernmental Panel on Climate Change, edited by: Solomon, S., Qin, D., Manning, M., et al., Cambridge University Press, Cambridge, UK and New York, NY, USA, 2007.

Chu, D. A.: Evaluation of aerosol properties over ocean from Moderate Imaging Spectroradiometer (MODIS) during ACE-Asia, J. Geophys. Res., 110, D07308, doi:10.1029/2004JD005208, 2005.

Clarke, A. D.: In-situ measurements of the aerosol size distributions, physicochemistry, and light absorption properties of Arctic haze. J. Atmos. Chem. 9, 255-267, 1989.

Clarke, A. D., and Noone, K. J.: Soot in Arctic snow: a cause for perturbations of radiative transfer. Atmos. Environ., 19, 20452053, 1985.

Clarke, A., McNaughton, C., Kapustin, V., et al.: Biomass burning and pollution aerosol over North America: Organic components and their influence on spectral optical properties and humidification response, J. Geophys. Res., 112, D12S18, doi:10.1029/2006JD007777, 2007.

Cleary, P. A., Wooldridge, P. J., and Cohen, R. C.: Laser-induced fluorescence detection of atmospheric $\mathrm{NO}_{2}$ using a commercial diode laser and a supersonic expansion, Appl. Opt., 41, 69506956, 2002.

Colarco, P. R., Schoeberl, M. R., Doddridge, B. G., Marufu, L. T., Torres, O., and Welton, E. J. : Transport of smoke from Canadian forest fires to the surface near Washington, D.C.: injection height, entrainment and optical properties. J. Geophys. Res., 109, D06203, doi:10.1029/2003JD004248, 2004.

Cox, P., Delao, A., Komorniczak, A., and Weller, R.: The California Almanac of emissions and air quality-2008 edition, California Air Resources Board, Sacramento, California, 2008.

Crounse, J., McKinney, K. A., Kwan, A. J., et al.: Measurement of gas-phase hydroperoxides by chemical ionization mass spectrometry, Anal. Chem., 78, 6726-6732, 2006.

Crounse, J. D., DeCarlo, P. F., Blake, D. R., Emmons, L. K., Campos, T. L., Apel, E. C., Clarke, A. D., Weinheimer, A. J., McCabe, D. C., Yokelson, R. J., Jimenez, J. L., and Wennberg, P. O.: Biomass burning and urban air pollution over the Cen- tral Mexican Plateau, Atmos. Chem. Phys., 9, 4929-4944, doi:10.5194/acp-9-4929-2009, 2009.

DeCarlo, P. F., Dunlea, E. J., Kimmel, J. R., Aiken, A. C., Sueper, D., Crounse, J., Wennberg, P. O., Emmons, L., Shinozuka, Y., Clarke, A., Zhou, J., Tomlinson, J., Collins, D. R., Knapp, D., Weinheimer, A. J., Montzka, D. D., Campos, T., and Jimenez, J. L.: Fast airborne aerosol size and chemistry measurements above Mexico City and Central Mexico during the MILAGRO campaign, Atmos. Chem. Phys., 8, 4027-4048, doi:10.5194/acp8-4027-2008, 2008.

Deeter, M. N., D. P. Edwards, J. C. Gille, and J. R. Drummond: CO retrievals based on MOPITT near-infrared observations, J. Geophys. Res., 114, D04303, doi:10.1029/2008JD010872, 2009.

Deeter, M. N., Edwards, D. P., Gille J. C., et al.: The MOPITT version $4 \mathrm{CO}$ product: Algorithm enhancements, validation, and long-term stability, J. Geophys. Res., 115, D07306, doi:10.1029/2009JD013005, 2010.

Diskin, G. S., Podolske, J. R., Sachse, G. W., and Slate, T. A.: Open-Path Airborne Tunable Diode Laser Hygrometer, in Diode Lasers and Applications in Atmospheric Sensing, SPIE Proceedings 4817, edited by: Fried, A., 196-204, 2002.

Emmons, L. K., Hess, P., Klonecki, A., et al.: Budget of tropospheric ozone during TOPSE from two chemical transport models, J. Geophys. Res., 108, 8372, doi:10.1029/2002JD002665, 2003.

Emmons, L. K., Walters, S., Hess, P. G., Lamarque, J.-F., Pfister, G. G., Fillmore, D., Granier, C., Guenther, A., Kinnison, D., Laepple, T., Orlando, J., Tie, X., Tyndall, G., Wiedinmyer, C., Baughcum, S. L., and Kloster, S., Description and evaluation of the Model for Ozone and Related Chemical Tracers, version 4 (MOZART-4), Geosci. Model Dev., 3, 43-67, 2010.

Fenn, M. A., Browell, E. V., Butler, C. F., et al.: Ozone and aerosol distributions and air mass characteristics over the South Pacific during the burning season, J. Geophys. Res., 104, 16197-16212, 1999.

Fiebig, M., Petzold, A., Wandinger, U., et al.: Optical closure for an aerosol column: method, accuracy, and inferable properties, applied to a biomass burning aerosol and its radiative forcing. J. Geophys. Res., 107, 192, 8133, doi:10.1029/2000JD000192, 2002.

Fiebig, M., Stohl, A., Wendisch, M., Eckhardt, S., and Petzold, A.: Dependence of solar radiative forcing of forest fire aerosol on ageing and state of mixture, Atmos. Chem. Phys., 3, 881-891, doi:10.5194/acp-3-881-2003, 2003.

Fisher, J. A., Jacob, D. J., Purdy, M. T., Kopacz, M., Le Sager, P., Carouge, C., Holmes, C. D., Yantosca, R. M., Batchelor, R. L., Strong, K., Diskin, G. S., Fuelberg, H. E., Holloway, J. S., Hyer, E. J., McMillan, W. W., Warner, J., Streets, D. G., Zhang, Q., Wang, Y., and Wu, S.: Source attribution and interannual variability of Arctic pollution in spring constrained by aircraft (ARCTAS, ARCPAC) and satellite (AIRS) observations of carbon monoxide, Atmos. Chem. Phys., 10, 977-996, doi:10.5194/acp-10-977-2010, 2010.

Flanner, M. G., Zender, C. S., Randerson, J. T., and Rasch, P. J.: Present-day radiative forcing and climate response from black carbon in snow, J. Geophys. Res., 112, D11202, doi:10.1029/2006JD008003, 2007.

Flannigan, M. D., Logan, K. A., Amiro, B. D., Skinner, W. R., and Stocks, B. J.: Future area burned in Canada, Clim. Change, 72, 
$1-16,2005$.

Freitas, S. R., Longo, K. M., Chatfield, R., Latham, D., Silva Dias, M. A. F., Andreae, M. O., Prins, E., Santos, J. C., Gielow, R., and Carvalho Jr., J. A.: Including the sub-grid scale plume rise of vegetation fires in low resolution atmospheric transport models, Atmos. Chem. Phys., 7, 3385-3398, doi:10.5194/acp-7-33852007, 2007.

Fried, A., Walega, J. G., Olson, .R., et al.: Formaldehyde over North America and the North Atlantic during the summer 2004 INTEX campaign: methods, observed distributions, and measurement-model comparisons, J. Geophys. Res., 113, D10302, doi:10.1029/2007JD009185, 2008.

Fromm, M. D., and Servranckx, R.: Transport of forest fire smoke above the tropopause by supercell convection, Geophys. Res. Lett., 30, 1542, doi:10.1029/2002GL016820, 2003.

Fuelberg, H. E., Kiley, C., Hannan, J. R., Westberg, D. J., Avery, M. A., and Newell, R. E.: Meteorological conditions and transport pathways during the transport and chemical evolution over the Pacific (TRACE-P) experiment, J. Geophys. Res., 108, 8782, doi:10.1029/2002JD003092, 2003.

Fuelberg, H. E., Harrigan, D. L., and Sessions, W.: A meteorological overview of the ARCTAS 2008 mission, Atmos. Chem. Phys., 10, 817-842, doi:10.5194/acp-10-817-2010, 2010.

Gatebe, C. K., King, M. D., Platnick, S., Arnold, G. T., Vermote, E. F., and Schmid, B.: Airborne spectral measurements of surface-atmosphere anisotropy for several surfaces and ecosystems over southern Africa, J. Geophys. Res., 108, 9489, doi:10.1029/2002JD002397, 2003.

Gatebe, C. K., Dubovik, O., King, M. D., and Sinyuk, A.: Simultaneous retrieval of aerosol and surface optical properties from combined airborne- and ground-based direct and diffuse radiometric measurements, Atmos. Chem. Phys., 10, 2777-2794, 2010, http://www.atmos-chem-phys.net/10/2777/2010/.

Generoso, S., Bey, I., Attie, J.-L., and Breon, F.-M.: A satelliteand model-based assessment of the 2003 Russian forest fires: impact on the Arctic region, J. Geophys. Res., 112, D15302, doi:10.1029/2006JD008344, 2007.

Gillett, N. P., A. J. Weaver, F. W. Zwiers, and Flannigan, M. D.: Detecting the effect of climate change on Canadian forest fires. Geophys. Res. Lett., 31, L18211, doi:10.1029/2004GL020876, 2004.

Girardin, M. P: Interannual to decadal changes in area burned in Canada from 1781 to 1982 and the relationship to Northern Hemisphere land temperatures, Global Ecol. Biogeogr., 16, 557566, 2007

Goode, J. G., Yokelson, R. G., Ward, D. E., et al.: Measurements of excess $\mathrm{O}_{3}, \mathrm{CO}_{2}, \mathrm{CO}, \mathrm{CH}_{4}, \mathrm{C}_{2} \mathrm{H}_{4}, \mathrm{C}_{2} \mathrm{H}_{2}, \mathrm{HCN}, \mathrm{NO}, \mathrm{NH}_{3}$, $\mathrm{HCOOH}, \mathrm{CH}_{3} \mathrm{COOH}, \mathrm{HCHO}$, and $\mathrm{CH}_{3} \mathrm{OH}$ in 1997 Alaskan biomass burning plumes by airborne Fourier transform infrared spectroscopy (AFTIR). J. Geophys. Res., 105, 22147-22166, 2000.

Goodsite, M. E., Plane, J. M. C., and Skov, H.: A theoretical study of the oxidation of $\mathrm{Hg}-0$ to $\mathrm{HgBr}_{2}$ in the troposphere, Environ. Sci. Technol. 38, 1772-1776, 2004.

Grannas, A. M., Jones, A. E., Dibb, J., Ammann, M., Anastasio, C., Beine, H. J., Bergin, M., Bottenheim, J., Boxe, C. S., Carver, G., Chen, G., Crawford, J. H., Dominé, F., Frey, M. M., Guzmán, M. I., Heard, D. E., Helmig, D., Hoffmann, M. R., Honrath, R. E., Huey, L. G., Hutterli, M., Jacobi, H. W., Klán, P., Lefer, B.,
McConnell, J., Plane, J., Sander, R., Savarino, J., Shepson, P. B., Simpson, W. R., Sodeau, J. R., von Glasow, R., Weller, R., Wolff, E. W., and Zhu, T.: An overview of snow photochemistry: evidence, mechanisms and impacts, Atmos. Chem. Phys., 7, 4329-4373, doi:10.5194/acp-7-4329-2007, 2007.

Grell, G. A., Peckham, S. E., Schmitz, R., McKeen, S. A., Frost, G., Skamarock, W. C., and Eder, B.: Fully coupled "online" chemistry within the WRF model, Atmos. Environ., 39, 6957-6975, 2005.

Hair, J. W., Hostetler, C. A., Cook, A. L., Harper, D. B., Ferrare, R. A., Mack, T. L., Welch, W.,, Izquierdo, L. R., and Hovis, F. E.: Airborne High Spectral Resolution Lidar for profiling aerosol optical properties, Appl. Optics, 47, 6734-6752, doi:10.1364/AO.47.006734, 2008

Hansen, J. and Nazarenko, L.: Soot climate forcing via snow and ice albedos, Proc. Natl. Acad. Sci., 101, 423-428, 2004.

Hecobian, A., Weber, R., Jimenez, J., et al., A comparison of the gas/aerosol emissions and evolution of 490 biomass burning plumes intercepted by the NASA DC8 aircraft during the ARCTAS/CARB-2008 field campaign, Atmos. Chem. Phys. Discuss., submitted, 2010.

Hirdman, D., Apsmo, K., Burkhart, J. F., et al.:, Transport of mercury in the Arctic atmosphere: Evidence for a springtime net sink and summer-time source, Geophys. Res. Lett., 36, L12814, doi:10.1029/2009GL038345, 2009.

Hoell, J. M., Davis, D. D., Jacob, D. J., et al.: Pacific Exploratory Mission - West Phase B: February-March 1994, J. Geophys. Res., 102, 28223-28240, 1997.

Holben, B. N., Tanré, D., Smirnov, A., Eck, T. F., Slutsker, I., Chatenet, B., Lavenue, F., Kaufman, Y., Castle, J. V., Setzer, A., Markham, B., Clark, D., Frouin, R., Karneli, N. A., O’Neill, N. T., Pietras, C., Pinker, R., Voss, K., and Zibordi, G.: An emerging ground-based aerosol climatology: Aerosol Optical Depth from AERONET, J. Geophys. Res., 106, 12067-12097, 2001.

Hollwedel, J., Wenig, M., Beirle, S., et al.: Year-ro-year variations of springtime polar tropospheric $\mathrm{BrO}$ as seen by GOME. Adv. Space Res., 34, 804-808, 2004.

Hyer, E. J., Allen, D. J., and Kasischke, E. S.: Examining injection properties of boreal forest fires using surface and satellite measurements of CO transport, J. Geophys. Res., 112, D18307, doi:10.1029/2006JD008232, 2007.

Jacob, D. J., Wofsy, S. C., Bakwin, P. S., Fan, S.-M., Harriss, R. C., Talbot, R. W., Bradshaw, J., Sandholm, S., Singh, H. B., Gregory, G. L., Browell, E. V., Sachse, G. W., Blake, D. R., and Fitzjarrald, D. R.: Summertime photochemistry at high northern latitudes, J. Geophys. Res., 97, 16421-16431, 1992.

Jacob, D. J., Logan, J. A., and Murti, P. P.: Effect of rising Asian emissions on surface ozone in the United States, Geophys. Res. Lett., 26(14), 2175-2178, 1999.

Jacob, D. J., Crawford, J. H., Kleb, M. M., Connors, V. S., Bendura, R. J., Raper, J. L., Sachse, G. W., Gille, J. C., Emmons, L., and Heald, C. L.: The Transport and Chemical Evolution over the Pacific (TRACE-P) aircraft mission: design, execution, and first results, J. Geophys. Res., 108, 9000, doi:10.1029/2002JD003276, 2003.

Kahn, R., Gaitley, B., Martonchik, J., Diner, D., Crean, K., and Holben, B.: MISR global aerosol optical depth validation based on two years of coincident AERONET observations, J. Geophys. Res. 110, doi:10:1029/2004JD004706, D10S04, 2005. 
Kahn, R. A., Li, W.-H., Moroney, C., Diner, D. J., Martonchik, J. V., and Fishbein, E.: Aerosol source plume physical characteristics from space-based multiangle imaging, J. Geophys. Res., 112, D11205, doi:10.1029/2006JD007647, 2007.

Kim, S., Huey, L. G., Stickel, R. E. J., Tanner, D. J., Crawford, J. H., Olson, J. R., Chen, G., Brune, W. H., Ren, X., Lesher, R., Wooldridge, P. J., Bertram, T. H., Perring, A., Cohen, R. C., Lefer, B., Shetter, R. E., Avery, M., Diskin, G., and Sokolik, I.: Measurement of pernitric acid in the free troposphere during the intercontinental chemical transport experiment - North America 2004, J. Geophys. Res., 112, D12S01, doi:10.1029/2006JD007676, 2007.

Kim, S. Y., Talbot, R., Mao, H., Blake, D. R., Huey, G., and Weinheimer, A. J., Chemical transformations of $\mathrm{Hg}^{\circ}$ during Arctic mercury depletion events sampled from the NASA DC-8, Atmos. Chem. Phys. Discuss., 10, 10077-10112, 2010, http://www.atmos-chem-phys-discuss.net/10/10077/2010/.

Kivi, R., Kyro, E., Turunen, T., et al.: Ozonesonde observations in the Arctic during 1989-2003: ozone variability and trends in the lower stratosphere and free troposphere, J. Geophys. Res., 112, D08306, doi:10.1029/2006JD007271, 2007.

Kleb, M. M., Chen, G., Belli, K., Crawford, J., and Rowell, A.: Overview of POLARCAT intercomparisons, presented at the Fall 2009 meeting of the American Geophysical Union, San Francisco, California, USA, 2009.

Klonecki, A., Hess, P., Emmons, L., Smith, L., and Orlando, J.: Seasonal changes in the transport of pollutants into the Arctic troposphere - model study, J. Geophys. Res., 108, 8367, doi:10.1029/2002JD002199, 2003.

Koch, D. and Hansen, J.: Distant origins of Arctic black carbon: a Goddard Institute of Space Studies Model E experiment, J. Geophys. Res., 110, D04204, doi:10.1029/2004JD005296, 2005.

Koike, M., Kondo, Y., Kita, K., et al.: Export of anthropogenic reactive nitrogen and sulfur compounds from the east Asia region in spring. J. Geophys. Res., 108, 8789, doi: 10.1029/2002JD003284, 2003.

Koo, J., Wang, Y., Choi, S., et al.: Arctic tropospheric ozone depletion during spring 2008 : source regions and transport, presented at the Fall 2009 meeting of the American Geophysical Union, San Francisco, California, USA, 2009.

Kylling, A., Webb, A. R., Kift, R., Gobbi, G. P., Ammannato, L., Barnaba, F., Bais, A., Kazadzis, S., Wendisch, M., Jkel, E., Schmidt, S., Kniffka, A., Thiel, S., Junkermann, W., Blumthaler, M., Silbernagl, R., Schallhart, B., Schmitt, R., Kjeldstad, B., Thorseth, T. M., Scheirer, R., and Mayer, B.: Spectral actinic flux in the lower troposphere: measurement and 1-D simulations for cloudless, broken cloud and overcast situations, Atmos. Chem. Phys., 5, 1975-1997, doi:10.5194/acp-5-1975-2005, 2005.

Labonne, M., Breon, F.-M., and Chevallier, F.: Injection height of biomass burning aerosols as seen from a spaceborne lidar, Geophys. Res. Lett., 34, L11806, doi:10.1029/2007GL029311 ,2007.

Lance, S., Medina, J., Smith, J. N., and Nenes, A.: Mapping the operation of the DMT Continuous Flow CCN counter, Aerosol Sci. Technol., 40, 242-254, 2006.

Lavoue, D., Liousse, C., Cachier, H., Stocks, B. J., and Goldammer, J. G.: Modeling of carbonaceous particles emitted by boreal and temperate wildfires at northern latitudes. J. Geophys. Res., 105, 26871-26890, 2000.

Law, K. S., and Stohl, A.: Arctic air pollution: origins and impacts,
Science, 315, 1537-1540, 2007.

Lemke, P., Ren, J, Alley, R. B., et al.: in Climate Change 2007: The Physical Science Basis. Contribution of Working Group I to the Fourth Assessment Report of the Intergovernmental Panel on Climate Change, edited by: Solomon, S., Qin, D., Manning, M., et al., Cambridge University Press, Cambridge, UK and New York, NY, USA, 2007.

Leung, F.-Y. T., Logan, J. A., Park, R., et al.: Impacts of enhanced biomass burning in the boreal forests in 1998 on tropospheric chemistry and the sensitivity of model results to the injection height of emissions. J. Geophys. Res., 112, D10313, doi:doi:10.1029/2006JD007281, 2007.

Levelt, P. F., Hilsenrath, E., Leppenmeier, G. W., van den Oord, G. H. J., Bhartia, P. K., Tamminen, J., de Haan, J. F., and Veefkind, J. P.: Science objectives of the Ozone Monitoring Instrument, IEEE Trans. Geosci. Remote Sens., 44, 1199-1208, 2006.

Liang, Q., Douglass, A. R., Duncan, B. N., Stolarski, R. S., and Witte, J. C.: The governing processes and timescales of stratosphere-to-troposphere transport and its contribution to ozone in the Arctic troposphere, Atmos. Chem. Phys., 9, 30113025, doi:10.5194/acp-9-3011-2009, 2009.

Livesey, N. J., Filipiak, M. J., Froidevaux, L., et al.: Validation of Aura Microwave Limb Sounder $\mathrm{O}_{3}$ and $\mathrm{CO}$ observations in the upper troposphere and lower stratosphere, J. Geophys. Res., 113, D15S02, doi:10.1029/2007JD008805, 2008.

Logan, J. A.: Tropospheric ozone - seasonal behavior, trends, and anthropogenic influence. J. Geophys. Res., 90, 10463-10482, 1985.

Lyapustin, A., Gatebe, C. K., Kahn, R., Brandt, R., Redemann, J., Russell, P., King, M. D., Pedersen, C. A., Gerland, S., Poudyal, R., Marshak, A., Wang, Y., Schaaf, C., Hall, D., and Kokhanovsky, A.: Analysis of snow bidirectional reflectance from ARCTAS Spring-2008 Campaign, Atmos. Chem. Phys., 10, 4359-4375, doi:10.5194/acp-10-4359-2010, 2010.

Mao, H., Talbot, R. W., Sive, B. C., et al.: Arctic Mercury Depletion and its Quantitative Link with Halogens, submitted, Atmos. Chem. Phys., 2010.

Mao, J., Jacob, D. J., Evans, M. J., et al., Chemistry of hydrogen oxide radicals $\left(\mathrm{HO}_{\mathrm{x}}\right)$ in the Arctic troposphere in spring, submitted, Atmos. Chem. Phys., 2010.

McMillan, W. W., Warner, J. X., Conner, M. M., et al.: AIRS views transport from 12 to 22 July 2004 Alaskan/Canadian fires: correlation of AIRS CO and MODIS AOD with forward trajectories and comparison of AIRS CO retrievals with DC-8 in situ measurements during INTEX-A/ICARTT, J. Geophys. Res., 113, D20301, doi:10.1029/2007JD009711, 2008.

McNaughton, C. S., Thornhill, L., Clarke, A. D., Howell, S. G., Pinkerton, M., Anderson, B., Winstead, E., Hudgins, C., Maring, H., Dibb, J. E., and Scheuer, E.: Results from the DC-8 inlet characterization experiment (DICE): Airborne versus surface sampling of mineral dust and sea salt aerosols, Aerosol Sci. Technol., 40, 136-159, 2007.

Morris, G. A., Hersey, S., Thompson, A. M., Stohl, A., Colarco, P. R., McMillan, W. W., Warner, J., Johnson, B. J., Witte, J. C., Kucsera, T. L., Larko, D. E., and Oltmans, S. J.: Alaskan and Canadian forest fires exacerbate ozone pollution in Houston, Texas, on 19 and 20 July 2004, J. Geophys. Res., 111, doi:10.1029/2006JD007441, D24S03, 2006.

Moteki, N. and Kondo, Y.: Effects of mixing state on black carbon 
measurements by Laser-Induced Incandescence, Aerosol Sci. Technol., 41, 398-417, 2007.

Moteki, N. and Kondo, Y.: Method to measure time-dependent scattering cross sections of particles evaporating in a laser beam, J. Aerosol Sci., 39, 348-364, 2008.

Munro, R., Eisinger, M., Anderson, C., Callies, J., Corpaccioli, E., Lang, R., Lefebvre, A., Livschitz, Y., and Albiñana, A. P.: GOME-2 on MetOp, Proc. of The 2006 EUMETSAT Meteorological Satellite Conference, Helsinki, Finland, 12-16 June 2006, EUMETSAT P.48, 2006.

Miyazaki, Y., Kondo, Y., Koike, M., et al.: Synoptic-scale transport of reactive nitrogen over the western Pacific in spring, J. Geophys. Res., 108, 8788, doi:10.1029/2002JD003248, 2003.

Monks, P. S.: A review of the observations and origins of the spring ozone maximum, Atmos. Environ., 34, 3545-3561, 2000.

Nance, J. D., Hobbs, P. V., Radke, L. F., and Ward, D. E.: Airborne measurements of gases and particles from an Alaskan wildfire, J. Geophys. Res., 98,, 14873-14882, 1993.

Neuman, J. A., Nowak, J. B., Huey, L. G., Burkholder, J. B., Dibb, J. E., Holloway, J. S., Liao, J., Peischl, J., Roberts, J. M., Ryerson, T. B., Scheuer, E., Stark, H., Stickel, R. E., Tanner, D. J., and Weinheimer, A.: Bromine measurements in ozone depleted air over the Arctic Ocean, Atmos. Chem. Phys. Discuss., 10, $3827-$ 3860, doi:10.5194/acpd-10-3827-2010, 2010.

Olson, J. R., Crawford, J. H., Chen, G., Brune, W. H., Faloona, I. C., Tan, D., Harder, H., and Martinez, M.: A reevaluation of airborne HOx observations from NASA field campaigns, J. Geophys. Res., 111, D10301, 2006.

Oltmans, S. J., Lefohn, A. S., Harris, J. M., and Shadwick, D. S.: Background ozone levels of air entering the west coast of the US and assessment of longer-term changes, Atmos. Environ., 42, 6020-6038, 2008.

Oltmans, S. J., Lefohn, A. S., Harris, J. M., et al.,: Enhanced ozone over western North America from biomass burning in Eurasia during April 2008 as seen in surface and profile observations, Atmos. Environ., submitted, 2010.

O’Neill, N. T., Eck, T. F., Holben, B. N., Smirnov, A., Royer, A., and Li, Z.: Optical properties of boreal fores fire smoke derived from Sun photometry, J. Geophys. Res., 107, 4125, doi:10.1029/2001JD000877, 2002.

Park, R. J., Jacob, D. J., Palmer, P. I., Clarke, A. D., Weber, R. J., Zondlo, M. A., Eisele, F. L., Bandy, A. R., Thornton, D. C., Sachse, G. W., and Bond, T. C.: Export efficiency of black carbon aerosol in continental outflow: global implications, J. Geophys. Res., 110, D11205, doi:10.1029/2004JD005432, 2005.

Parrish, D. and Fehsenfeld, F.: Methods for gas-phase measurements of ozone, ozone precursors and aerosol precursors, Atmos. Env., 34, 1921-1957, 2000.

Pfister, G. G., Hess, P. G., Emmons, L. K., Rasch, P. J., and Vitt, F. M.: Impact of the summer 2004 Alaskan fires on top of the atmosphere clear-sky radiation fluxes. J. Geophys. Res., 113, D02204, doi:10.1029/2007JD008797, 2008.

Pickett-Heaps, C., Jacob, D. J., et al.: New estimate of methane emissions from the Hudson Bay Lowlands using aircraft observations from the ARCTAS and Pre-HIPPO campaigns, presented at the Fall Meeting of the American Geophysical Union, San Francisco, California, USA, 2009.

Preston, C. M., and Schmidt, M. W. I.: Black (pyrogenic) carbon: a synthesis of current knowledge and uncertainties with spe- cial consideration to boreal regions, Biogeosciences, 3, 397-420, 2006, http://www.biogeosciences.net/3/397/2006/.

Quinn, P. K., Shaw, G., Andrews, E., Dutton, E. G., Ruoho-Airola, T., and Gong, S. L.: Arctic haze: current trends and knowledge gaps, Tellus, 59B, 99-114, 2007.

Quinn, P. K., Bates, T. S., Baum, E., Doubleday, N., Fiore, A. M., Flanner, M., Fridlind, A., Garrett, T. J., Koch, D., Menon, S., Shindell, D., Stohl, A., and Warren, S. G.: Short-lived pollutants in the Arctic: their climate impact and possible mitigation strategies, Atmos. Chem. Phys., 8, 1723-1735, doi:10.5194/acp8-1723-2008, 2008

Rahn, K. A.: Relative importances of North America and Eurasia as sources of Arctic aerosol, Atmos. Environ., 15, 1447-1455, 1981.

Radke, L. F., Lyons, J. H., Hegg, D. A., Hobbs, P. V., and Bailey, I. H.: Airborne observations of Arctic aerosols, I, Characteristics of Arctic haze, Geophys. Res. Lett., 11, 393-396, 1984.

Radke, L. F., Hegg, A. S., Hobbs, P. V., and Penner, J. E.: Effect of aging on the smoke of a large forest fire, Atmos. Res., 38, 315-332, 1995.

Real, E., Law, K., Weinzierl, B., et al.: Processes influencing ozone in Alaskan forest fire plumes during long-range transport over the North Atlantic. J. Geophys. Res., 112, D10S41, doi: 10.1029/2007JD008797, 2007.

Reid, J. S., Koppmann, R., Eck, T. F., and Eleuterio, D. P.: A review of biomass burning emissions part II: intensive physical properties of biomass burning particles, Atmos. Chem. Phys., 5, 799825, doi:10.5194/acp-5-799-2005, 2005.

Remer, L., Kaufman, Y. J., Tanré, D., Mattoo, S., Chu, D. A., Martins, J. V., Li, R.-R., Ichoku, C., Levy, R. C., Kleidman, R. G., Eck, T. F., Vermote, E., and Holben, B. N.: The MODIS aerosol algorithm, products and validation, J. Atmos. Sci., 62, 947-973, 2005.

Ren, X., Olson, J. R., Crawford, J. H., et al.: $\mathrm{HO}_{\mathrm{x}}$ chemistry during INTEX-A 2004: observation, model calculation, and comparison with previous studies, J. Geophys. Res., 113, D05310, doi:10.1029/2007JD009166, 2008.

Ridley, B. A., Atlas, E. L., Montzka, D. D., et al.: Ozone depletion events in the high latitude surface layer during the TOPSE aircraft program. J. Geophys. Res., 108, 8356, doi: doi:10.1029/2001JD001507, 2003.

Roberts, G. C. and Nenes, A.: A continuous-flow streamwise thermal-gradient $\mathrm{CCN}$ chamber for atmospheric measurements, Aerosol Sci. Technol., 39, 206-221, 2005.

Roulet, N. T., Jano, A., Kelly, C. A., Klinger, L. F., Moore, T. R., Protz, R., Ritter, J. A., and Rouse, W. R.: Role of the Hudson Bay Lowland as a source of atmospheric methane, J. Geophys. Res., 99, 1439-1454, 1994.

Russell, P. B., Livingston, J. M., Redemann, J., et al.: Multigrid-cell validation of satellite aerosol property retrievals in INTEX/ITCT/ICARTT 2004, J. Geophys. Res., 112, D12S09, doi:10.1029/2006JD007606, 2007.

Sachse, G. W., Hill, G. F., Wade, L. O., and Perry, M. G.: Fastresponse, highprecision carbon monoxide sensor using a tunable diode laser absorption technique, J. Geophys. Res., 92, 20712081, 1987.

Saha, A., O’Neill, N. T., Eloranta, E., et al.: Pan-Arctic sunphotometry during the ARCTAS-A campaign of April 2008, Geophys. Res. Lett., in press, 2010. 
Salawitch, R. J., Canty, T., Kurosu, T., et al.: A new interpretation of total column BrO, submitted Geophys. Res. Lett., 2010.

Scheuer, E., Talbot, R. W., Dibb, J. E., Seid, G. K., deBell, L., and Lefer, G.: Seasonal distributions of fine aerosol sulfate in the North American Arctic Basin during TOPSE, J. Geophys. Res., 108, 8370, doi:doi:10.1029/2001JD001364, 2003.

Schnell, R. C.: Arctic haze and the Arctic Gas and Aerosol Sampling Program (AGASP), Geophys. Res. Lett., 11, 361-364, 1984.

Schwarz, J. P., et al., Single-particle measurements of midlatitude black carbon and light-scattering aerosols from the boundary layer to the lower stratosphere, J. Geophys. Res., 111, D16207, doi:10.1029/2006JD007076, 2006.

Schoeberl., M. R.: A trajectory-based estimate of the tropospheric ozone column using the residual method. J. Geophys. Res., 112, D24S49, doi:10.1029/2007JD008773, 2007.

Sessions, W. R., Fuelberg, H. E., Kahn, R., et al.: Transport simulations of carbon monoxide and aerosols from boreal wildfires during ARCTAS using WRF-Chem Atmos. Chem. Phys., submitted, 2010.

Shaw, G. E: The Arctic haze phenomenon, BAMS, 2403-2413, 1995.

Shetter, R. E. and Muller, M.: Photolysis frequency measurements on the NASA DC-8 during the PEM-Tropics Mission using actinic flux spectroradiometry: Instrument description and result (1999), J. Geophys. Res., 104, 5647-5661, 1999.

Shindell, D. T., Faluvegi, G., Bauer, S. E., et al.: Climate response to projected changes in short-lived species under an A1B scenario from 2000-2050 in the GISS climate model, J. Geophys. Res., 112, D20103, doi:10.1029/2007JD008753, 2007.

Shindell, D. T., Chin, M., Dentener, F., Doherty, R. M., Faluvegi, G., Fiore, A. M., Hess, P., Koch, D. M., MacKenzie, I. A., Sanderson, M. G., Schultz, M. G., Schulz, M., Stevenson, D. S., Teich, H., Textor, C., Wild, O., Bergmann, D. J., Bey, I., Bian, H., Cuvelier, C., Duncan, B. N., Folberth, G., Horowitz, L. W., Jonson, J., Kaminski, J. W., Marmer, E., Park, R., Pringle, K. J., Schroeder, S., Szopa, S., Takemura, T., Zeng, G., Keating, T. J., and Zuber, A.: A multi-model assessment of pollution transport to the Arctic, Atmos. Chem. Phys., 8, 5353-5372, doi:10.5194/acp-8-5353-2008, 2008.

Shindell, D. and Faluvegi, G.: Climate response to regional radiative forcing during the twentieth century, Nature Geosci., 2, 294 300, 2009.

Shinozuka, Y., J. Redemann, J. M. Livingston, P. B. Russell, R. Johnson, S. Ramachandran, A. D. Clarke, S. G. Howell, C. S. McNaughton, S. Freitag, V. N. Kapustin, V. Brekhovskikh, B. Holben, N. O’Neill, McArthur, E. Reid, Royer, Wagener: Airborne observation of aerosol optical depth during ARCTAS: Vertical profiles, inter-comparison, fine-mode fraction and horizontal variability, Atmos. Chem. Phys., submitted, 2010.

Simpson, W. R., von Glasow, R., Riedel, K., et al.: Halogens and their role in polar boundary-layer ozone depletion, Atmos. Chem. Phys., 7, 4375-4418, doi:10.5194/acp-7-4375-2007, 2007a.

Simpson, W. R., Carlson, D., Hnninger, G., Douglas, T. A., Sturm, M., Perovich, D., and Platt, U.: First-year sea-ice contact predicts bromine monoxide $(\mathrm{BrO})$ levels at Barrow, Alaska better than potential frost flower contact, Atmos. Chem. Phys., 7, 621-627, doi:10.5194/acp-7-621-2007, 2007b.
Simpson, I. J., Meinardi, S., Barletta, B., et al.: Characterization of trace gases measured near Alberta oil sands mining operations: 77 speciated $\mathrm{C}_{2}-\mathrm{C}_{10}$ volatile organic compounds (VOCs), $\mathrm{CO}_{2}$, $\mathrm{CO}, \mathrm{CH}_{4}, \mathrm{NO}, \mathrm{NO}_{\mathrm{y}}, \mathrm{O}_{3}$ and $\mathrm{SO}_{2}$, Atmos. Chem. Phys., submitted, 2010.

Singh, H. B., Brune, W. H., Crawford, J. H., Flocke, F., and Jacob, D. J.: Chemistry and transport of pollution over the Gulf of Mexico and the Pacific: spring 2006 INTEX-B campaign overview and first results, Atmos. Chem. Phys., 9, 2301-2318, doi:10.5194/acp-9-2301-2009, 2009.

Singh, H. B., Anderson, B. E., Brune, W. H., et al.: Pollution influences on atmospheric composition and chemistry at high northern latitudes: Boreal and California forest fire emissions, Atmos. Environ., submitted, 2010.

Slusher, D. L., Huey, L. G., Tanner, D. J., Flocke, F. M., and Roberts, J. M.: A thermal dissociation-chemical ionization mass spectrometry (TD-CIMS) technique for the simultaneous measurement of peroxyacyl nitrates and dinitrogen pentoxide, J. Geophys. Res., 109, D19315, doi:10.1029/2004JD004670, 2004.

Soja, A. J., Tchebakova, N. M., French, N. H. F., et al.: Climateinduced boreal forest change: predictions versus current observations, Global Planet. Change, 56, 274-296, 2007.

Soja, A. J., Stocks, B., Maczeck, P., Fromm, M., Servranckx, R., and Turetsky, M., and Benscoter, B.: ARCTAS: the perfect smoke, The Canadian Smoke Newsletter, Fall 2008, 2-7, 2008.

Spencer, K. M., Crounse, J. D., St. Clair, J. M., et al.: Changes in the South Coast Air Basin atmospheric sulfur budget between 2002 and 2008, presented at the Fall 2009 Meeting of the American Geophysical Union, San Francisco, California, USA, 2009.

Steffen, A., Douglas, T., Amyot, M., Ariya, P., Aspmo, K., Berg, T., Bottenheim, J., Brooks, S., Cobbett, F., Dastoor, A., Dommergue, A., Ebinghaus, R., Ferrari, C., Gardfeldt, K., Goodsite, M. E., Lean, D., Poulain, A. J., Scherz, C., Skov, H., Sommar, J., and Temme, C.: A synthesis of atmospheric mercury depletion event chemistry in the atmosphere and snow, Atmos. Chem. Phys., 8, 1445-1482, doi:10.5194/acp-8-1445-2008, 2008.

Stocks, B. J., Fosberg, M. A., Lynham, T. J., et al.: Climate change and forest fire potential in Russian and Canadian boreal forests, Clim. Change, 38, 1-13, 1998.

Stohl, A.: A 1-year Lagrangian "climatology" of air streams in the Northern Hemisphere troposphere and lower stratosphere, J. Geophys. Res., 106, 7263-7279, 2001.

Stohl, A.: Characteristics of atmospheric transport into the Arctic troposphere. J. Geophys. Res., 111, D11306, doi:10.1029/2005JD006888, 2006.

Stone, R. S., Anderson, G. P., Shettle, E. P., et al.: Radiative impact of boreal smoke in the Arctic: observed and modeled. J. Geophys. Res., 113, D14S16, doi:10.1029/2007JD009657, 2008.

Strawa, A. W., Elleman, R., Hallar, A. G., et al.: Comparison of in situ aerosol extinction and scattering coefficient measurements made during the Aerosol Intensive Operating Period, J. Geophys. Res., 111, D05S03, doi:10.1029/2005JD006056, 2006.

Streets, D. G., Zhang, Q., Wang, L. T., et al.: Revisiting China's $\mathrm{CO}$ emissions after the Transport and Chemical Evolution over the Pacific (TRACE-P) mission: Synthesis of inventories, atmospheric modeling, and observations, J. Geophys. Res., 111, D14306, doi:10.1029/2002JD003093, 2006.

Sullivan, A., Peltier, R. E., Brock, C. A., Gouw, J. A. d., Holloway, J. S., Warneke, C., Wollny, A. G., and Weber, R. J.: Airborne 
measurements of carbonaceous aerosol soluble in water over northeastern United States: Method development and an investigation into water-soluble organic carbon sources, J. Geophys. Res., 111, D23S46, doi:10.1029/2006JD007072, 2006.

Talbot, R., Mao, H., Scheuer, E., Dibb, J., Avery, M., Browell, E., Sachse, G., Vay, S., Blake, D., Huey, G., and Fuelberg, H.: Factors influencing the large-scale distribution of $\mathrm{Hg}^{\circ}$ in the Mexico City area and over the North Pacific, Atmos. Chem. Phys., 8, 2103-2114, doi:10.5194/acp-8-2103-2008, 2008.

Tarasick, D. W., Fioletov, V. E., Wardle, D. I., Kerr, J. B., and Davies, J.: Changes in the vertical distribution of ozone over Canada from ozonesondes: 1980-2001, J. Geophys. Res., 110, D02304, doi:10.1029/2004JD004643, 2005.

Tarasick, D. W., Moran, M. D., Thompson, A. M., et al.: Comparison of Canadian air quality forecast models with tropospheric ozone profile measurements above mid-latitude North America during the IONS/ICARTT Campaign: Evidence for stratospheric input, J.Geophys. Res., 112, D12S22, doi:10.1029/2006JD007782, 2007.

Thompson, A. M., Stone, J. B., Witte, J. C., et al.: Intercontinental Transport Experiment Ozonesonde Network Study (IONS, 2004): 2. Tropospheric ozone budgets and variability over northeastern North America, J. Geophys. Res., 112, D12S13, doi:10.1029/2006JD007670, 2007.

Trenberth, K., Jones, P. D., Ambenje, P., et al.: in: Climate Change 2007: The Physical Science Basis. Contribution of Working Group I to the Fourth Assessment Report of the Intergovernmental Panel on Climate Change, edited by: Solomon, S., Qin, D., Manning, M., et al., Cambridge University Press, Cambridge, UK and New York, NY, USA, 2007.

Turetsky, M. R., Harden, J. W., Friedli, H. R., Flannigan, M., Payne, N., Crock, J., and Radke, L.: Wildfires threaten mercury stocks in northern soils, Geophys. Res. Lett., 33, L16403, doi:10.1029/2005GL025595, 2006.

Turquety, S., Logan, J. A., Jacob, D. J., Hudman, R. C., Leung, F. Y., Heald, C. L., Yantosca, R. M., Wu, S., Emmons, L. K., Edwards, D. P., and Sachse, G. W.: Inventory of boreal fire emissions for North America in 2004: the importance of peat burning and pyro-convective injection, J. Geophys. Res. 112, D12S03, doi:10.1029/2006JD007281, 2007.

Vay, S. A., Woo, J.-H., Anderson, B. E., Thornhill, K. L., Blake, D. R., Westberg, D. J., Kiley, C. M., Avery, M. A., Sachse, G. W., Streets, D., Tsutsumi, Y., and Nolf, S.: The influence of regional-scale anthropogenic emissions on $\mathrm{CO}_{2}$ distributions over the western North Pacific, J. Geophys. Res., 108, 8801, doi:10.1029/2002JD003094, 2003.

Wang, H., Jacob, D. J., Le Sager, P., Streets, D. G., Park, R. J., Gilliland, A. B., and van Donkelaar, A.: Surface ozone background in the United States: Canadian and Mexican pollution influences, Atmos. Environ., 43, 1310-1319, 2009.
Wang, Q., Jacob, D. J., Fisher, J. A., et al.: Sources and sinks of carbonaceous aerosols in the Arctic in spring, presented at the Fall Meeting of the American Geophysical Union, San Francisco, California, USA, 2009.

Waquet, F., Cairns, B., Knobelspiesse, K., Chowdhary, J., Travis, L. D., Schmid, B., and Mishchenko, M. I.: Polarimetric remote sensing of aerosols over land, J. Geophys. Res., 114, D01206, doi:10.1029/2008JD010619, 2009.

Warneke, C., Bahreini, R., Brioude, J., et al.: Biomass burning in Siberia and Kazakhstan as an important source for haze over the Alaskan Arctic in April 2008, Geophys. Res. Lett., 36, L02813, doi:10.1029/2008GL036194, 2009.

Weinheimer, A. J., Walega, J. G., Ridley, B. A., Gary, B. L., Blake, D. R., Blake, N. J., Rowland, F. S., Sachse, G. W., Anderson, B. E., and Collins, J. E.: Meridional distributions of $\mathrm{NO}_{\mathrm{x}}, \mathrm{NO}_{\mathrm{y}}$, and other species in the lower stratosphere and upper troposphere during AASE II, Geophys. Res. Lett., 21, 2583-2586, 1994.

Westphal, D. L., and Toon, O. B.: Simulations of microphysical, radiative, and dynamical processes in a continental-scale forest fire smoke plume. J. Geophys. Res., 96, 22379-22400, 1991.

Wetzel, M. A., Shaw, G. E., Slusser, J. R., Borys, R. D., and Cahill, C. F.: Physical, chemical, and ultraviolet radiative characteristics of aerosol in central Alaska, J. Geophys. Res., 108, 4418, 2003.

Winker, D. W., Hunt, W. H., and McGill, M. J.: Initial performance assessment of CALIOP. Geophys. Res. Lett., 34, L19803, doi:10.1029/2007GL030135, 2007.

Wisthaler, A., Hansel, A., Dickerson, R. R., et al.: Organic trace gas measurements by PTR-MS during INDOEX 1999, J. Geophys. Res., 107, 8024, doi:10.1029/2001JD000576, 2002.

Worden, H. M., Bowman, K. W., Worden, J. R., Eldering, A., and Beer, R.: Satellite measurements of the clear-sky greenhouse effect from tropospheric ozone, Nature Geosci., 1, 305-308, 2008.

Worthy, D. E. J., Levin, I., Hopper, F., Ernst, M. K., and Trivett, N. B. A.: Evidence for a link between climate and northern wetland methane emissions, J. Geophys. Res., 105, 4031-4038, 2000.

Zhang, L., Jacob, D. J., Boersma, K. F., Jaffe, D. A., Olson, J. R., Bowman, K. W., Worden, J. R., Thompson, A. M., Avery, M. A., Cohen, R. C., Dibb, J. E., Flock, F. M., Fuelberg, H. E., Huey, L. G., McMillan, W. W., Singh, H. B., and Weinheimer, A. J.: Transpacific transport of ozone pollution and the effect of recent Asian emission increases on air quality in North America: an integrated analysis using satellite, aircraft, ozonesonde, and surface observations, Atmos. Chem. Phys., 8, 6117-6136, doi:10.5194/acp-8-6117-2008, 2008.

Zeng, T., Wang, Y., Chance, K., et al.: Halogen-driven low-altitude $\mathrm{O}_{3}$ and hydrocarbon losses in spring at northern high latitudes. J. Geophys. Res., 111, D17313, doi:10.1029/2005JD006706, 2006. 